\title{
Macroeconomic Profitability: \\ Theory and Evidence
}

by

Thomas R. Michl

Working Paper No. 1

November 1987

The author wishes to thank The Jerome Levy Economics Institute for its financial support. For useful comments, he thanks Jeffrey Baldani, Samuel Bowles, Gerald Epstein, Steven Fazzari, Richard Kopke, David Kotz. David A. Levy, Michele Naples, Fred Moseley, Dimitri Papadimitriou, Robert Turner, Don Waldman, and Thomas Weisskopf. The author assumes responsibility for any errors. Any opinions expressed are those of the author and not necessarily those if The Jerome Levy Economics Institute. 
JLEI Working Paper \# 1 November 1987

Macroeconomic Profitability: Theory and Evidence

\section{ABSTRACT}

This paper gives an account of recent work on the measurement, statistical analysis, and theoretical analysis of macroeconomic profitability. Measurement issues include the treatment of holding gains on physical assets and net financial liabilities, national income accounting practices and recent revisions, and the use of accounting rates of return. Statistical work has focused on the identification of trends and shifts in profit rates not caused by cyclical fluctuations, and various theoretical explanations have been offered for the generally low rates of return that appeared in the $1970 \mathrm{~s}$. These include capital deepening stimulated by a reduction in the cost of capital funds; profit squeezes caused by some combination of slower productivity growth, real wage push, and raw material price inflation; declining capital productivity; and changes in effective tax rates.

The paper raises several questions. The use of a constant mark-up pricing model in reduced form to control for cyclical effects on profitability is questioned because of evidence that the mark-up is variable, and some suggestions for incorporating this evidence into applied studies of profitability are offerred. Several empirical puzzles are identified. The apparent decline in capital productivity is one; the more pronounced decline in before-tax profitability compared to after-tax profitability is another.

Thomas R. Michl

Department of Economics

Colgate University

Hamilton, NY 13346

$(315)-824-1000$ 
Table of Contents

INTRODUCTION

Page 1

I. The Measurement of Profits and Profitability 2

Concepts of capital income 3

Operating surplus 4

Capital consumption adjustments 8

Inventory valuation adjustment 9

$\begin{array}{ll}\text { Holding gains } & 10\end{array}$

Accounting rates of return 14

II. Studies of Macroeconomic Profitability 18

$\begin{array}{ll}\text { Cyclical adjustment } & 18\end{array}$

Studies of profitability in the U.S. 23

Studies of other industrial countries 26

What have we learned post-Nordhaus? 27

Decomposition of profitability 28

III. Explanations of Declining Profitability 34

Cost of funds 34

$\begin{array}{ll}\text { Import competition } & 37\end{array}$

Profit squeezes $\quad 38$

Investment and profitability 47

Some facts which resist stylization 49

Declining capital productivity 51

Taxes and profitability $\quad 55$

Concluding thoughts $\quad 62$

$\begin{array}{ll}\text { ENDNOTES } & 63\end{array}$

$\begin{array}{ll}\text { TABLES } & 69\end{array}$

FIGURES

$\begin{array}{lr}\text { BIBLIOGRAPHY } & 87\end{array}$ 
Introduction. The purpose of this paper is to give an account of the macroeconomics of profits: how they are determined, what is their significance, what is known about their behavior. I have chosen to concentrate on applied studies of macroeconomic profitability as the vehicle for organizing the views of a wide variety of economists. By macroeconomic profitability I mean the rate of return on physical capital, the object of analysis in the familiar macroeconomic growth model of your choice.

Three competing paradigms are represented in this survey: neoclassical, neo-Keynesian, and neo-Marxian economic theories. Rather than direct a frontal assault on the differences, I contrast the alternative interpretations of declining profitability in the 1970 s offered by representatives of each school of thought. 1

Recent efforts to understand the macroeconomics of profitability have revolved around three moments: the measurement of profitability, the identification of secular and cyclical movements in profitability, and the theoretical explanation of those movements. The paper's organization aligns with this natural structure. Tables and figures appear after the endnotes. 
The Measurement of Profits and Profitability

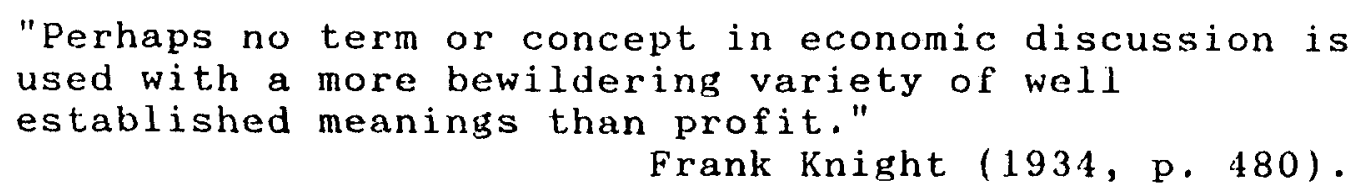

In a noninflationary world of family firms using one-period capital inputs with no taxes or debt, measuring profit would be a relatively straightforward matter of deducting expenses from receipts. The accountant's books and the economist's books would coincide. But in the presence of long-lived assets of various maturities, price changes, debt financing, and taxation, the two bookkeeping systems diverge and researchers face some difficult questions. Should profit-type income include net interest payments? How should holding gains on real assets or on net financial liabilities be treated? Should profitability be measured on gross capital stock (including depreciation in the numerator) or net stock (excluding depreciation), and indeed are average accounting rates of profit meaningful at all?

This section reviews the major measurement issues raised in applied studies of macroeconomic profitability, which excludes the narrower issue of returns on equity. Unless otherwise stated, the discussion is confined to nonfinancial corporations which account for about 65 to 70 per cent of total business gross domestic product in the U.S. The nonfinancial corporate sector is the universe of observation most often used in the studies of profitability reviewed in the next section. Since these studies were done, some revisions have been made in the national income 
accounts and these need to be carefully examined.

Concepts of capital income. Corporate earnings fall into

two broad categories: operating surplus and holding gains. These two categories are conflated in financial and tax accounts by the use of historical cost accounting for inventories in both accounts. National income accounts are based on the concept of income originating in current production, and thus are faccd with the task of removing holding gains from reported profits, but other concepts of income have been proposed that lcad to alternative practices.

Haig-Simons comprehensive income (Simons 1938), for instance, defines corporate profits as disbursements to stockholders plus change in net worth. This concept, which incorporates both realized and accrued real holding gains on both physical assets and net financial liabilities as income, has been proposed primarily for financial and tax accounting; see shoven and Bulow $(1975,1976)$. Including holding gains in profits is clearly justified in studies of returns to stockholder equity. In studies of macroeconomic profitability, however, the appropriate treatment of holding gains is less clear and will be discussed in greater detail below.

Most research is guided by Pigou-Marshall capital maintenance income (Pigou 1941), which deducts from gross income those expenses necessary to maintain physical capital intact. Only realized (not accrued) holding gains count as income by this concept, and in practice only holding gains on net financial 
liabilities are typically recognized. 2 As in financial

accounting, the firm is a "going concern" that does not stake out new positions in response to changes in asset values. For example, if its inventories of working capital rise in relative value the firm does not benefit from these accrued holding gains since they are absorbed by the higher price the firm must now pay for working capital. In eliminating holding gains on invéntories by applying last-in first-out (LIFO) accounting universally, national income accounts align closely with capital maintenance income, but in ignoring the effects of inflation on net financial liabilities they diverge from it. The studies we survey overcome this divergence by defining capital income to include net interest payments.

The central difference between Haig-Simons and PigouMarshall income is that the former conceives the firm as a portfolio manager which takes new positions in response to changes in asset and product prices, while the latter conceives the firm as a producing agent which reproduces its ability to continue production over time.

Operating surplus. I adopt the neutral term "operating surplus" out of respect for the heterogenous nature of capital income. With the exception of this term, I adopt the terminology of the U.S. Bureau of Economic Analysis's National Income and Product Accounts (NIPA). Operating surplus is value added minus compensation, indirect taxes net of subsidies, and depreciation at current costs. From the view of economic theory, operating 
surplus combines several disparate kinds of income: normal profits, monopoly profits, rents on new technologies, risk premia, and net interest payments. Ruggles and Ruggles suggest some heroic procedures for separating the normal profit element, which they estimate to be about half NIPA profits in 1966 (1970, p. 108). Opinions on the true value of the proportion of abovenormal profits range from zero (product and factor markets perfectly competitive) to nonnegligible. Hall (1986) finds evidence that firms earn returns above the Hall-Jorgenson rental cost of capital.

It is useful to distinguish between gross and net operating surplus, GOS and NOS. The use of historical cost accounting and the liberal provisions for depreciation permitted by tax codes require an inventory valuation adjustment (IVA) and a capital consumption adjustment (CCAdj), so that these operating surpluses are described by

$$
\begin{aligned}
& \text { GOS }=\text { PAT }+\mathrm{T}+\mathrm{CCA}+\mathrm{IVA}+\mathrm{R} \\
& \mathrm{NOS}=\mathrm{PAT}+\mathrm{T}+\mathrm{CCAd} j+\mathrm{IVA}+\mathrm{R}
\end{aligned}
$$

In these identities, PAT represents reported profits after tax, $T$ represents corporate income tax, $\mathrm{CCA}$ represents reported capital consumption allowances, and $R$ represents net interest paid. Measurement of these itemi in the U.S. NIPAs is discussed in order from left to right.

The procedures for assembling the data on PAT and $T$ are detailed with some precision in U.S. Department of Commerce, Bureau of Economic Analysis (1985A). Briefly, profits before tax 
(PBT), T, and PAT are derived from Internal Revenue Service records. Revisions are made in July when IRS data become available for annual data three years past. Annual and quarterly profits for the intervening intervals are based on extrapolations and interpolations from secondary sources, such as the Bureau of Census's Quarterly Financial Report. ${ }^{3}$ As IRS records becomé available the recent profit data are subject to revision. Since tax data are also necessary for the estimation of the capital consumption adjustments, the estimates of economic profits are subject to revisions too. In July 1986 the following revisions were released for nonfinancial corporations:

$\begin{array}{cc}\text { Profits } & \text { Profits } \\ \text { with IVA and } & \text { Before Tax }\end{array}$

Billions of dollars

$\begin{array}{ccccccc} & \text { New } & \text { Old } & \text { New } & \text { Old } & \text { New } & \text { Old } \\ 1983 & 165.5 & 160.6 & 159.3 & 151.5 & 17.1 & 19.0 \\ 1984 & 216.7 & 221.1 & 189.3 & 186.3 & 32.9 & 40.3 \\ 1985 & 224.2 & 240.7 & 170.3 & 172.3 & 54.5 & 69.0\end{array}$

SOURCE: NIPA Table 1.16, Survey of Current Business, March and July, 1986 .

Most of the change in economic profits originated in the reductions in CCAdj when new IRS data on the coverage of Accelerated Cost Recovery System depreciation became available (Survey of Current Business, July 1986, pp. 19-20). Later I discuss the advisability of using gross profitability, which does not depend on accurate estimates of economic depreciation.

Research and development expenditures are treated as a cost. in the NIPAs. Ruggles and Ruggles (1970, p. 108) observe that 
$R \& D$ is more akin to investment; treating it as a cost understates corporate profits. Another cost one is inclined to question is executive salaries. Does anyone really believe Victor Posner's marginal product is over eight million dollars?

Ruggles and Ruggles (1982) develop a system of integrated economic accounts differing from the existing NIPAs in a number of respects. Since they neither detail their procedures nor publish data (although it is available on magnetic tape) for the nonfinancial corporate sector, an evaluation of the effects of their accounting system on nonfinancial corporate operating surplus remains an interesting project. However, their accounting system for allocating saving between the enterprise sector (private domestic industry and government enterprise minus owner-occupied housing) and the household sector sheds light on a time-honored debate between neo-Keynesian/neo-Marxian and neoclassical economists about the role of profit-type income in generating saving for business capital accumulation. For an overview of this debate, consult Marglin (1984A). Briefly, neoKeynesian/neo-Marxian economists argue that business saving finances a sufficiently large proportion of business investment to justify theoretical models which suppress the role of saving out of wages.

By virtue of accounting practices that depart from NIPA procedures, e.g. allocating pension fund contributions to the gross saving of the enterprise sector (the sector that actually does the saving) rather than to the household sector (as the 
NIPAs do), Ruggles and Ruggles find that from 1947 to 1980 , "the enterprise sector's gross saving was 95 percent of its gross capital formation" (Ruggles and Ruggles 1982, p. 50), a picture that conforms closely to the neo-Keynesian/neo-Marxian theory. Capital consumption adjustments. The CCAdj corrects reported depreciation charges from tax accounts. Economic depreciation is calculated at current replacement cost using straight-line depreciation and retirements following a modified Winfrey s-3 distribution centered on realistic service lives. Actually there are two separate, opposing adjustments: CCAdj for consistent accounting at historical prices, and CCAdj for current replacement cost. The first takes account of tax code depreciation provisions, which have become progressively more liberal.4 The second corrects for historical cost accounting. Under inflation, historical cost accounting understates economic depreciation and overstates profits. Tax-based depreciation understates economic profits. The net effect on economic profits of these opposing adjustments has varied from positive to negative in different periods. The most spectacular adjustments occur in the 1980s when owing to the effects of liberalized depreciation schedules, as much as one fourth of after-tax economic profits are capital consumption adjustments.

Recent revisions in the NIPA capital stock model which forms the basis for the CCAdj have lengthened the average service lives of most durable equipment to conform with studies done by the Treasury Department (Gorman et al., 1985). Previously, service 
lives were taken to be .85 of the Bulletin F service lives originally compiled by the Treasury in 1942. Longer service lives generally reduce economic depreciation, and increase the CCAdj. Since macroeconomic profitability is usually measured as a ratio of net operating surplus to net capital stock this one revision has a dual effect. Tables 1 and 2 show recent revisions in the NIPAs for the corporate (including financial) sector. The net capital stock has grown more rapidly than previously estimated as seen by the rising values along the rows of Table 2 . Inventory valuation adjustments. The IVA removes holding gains on inventories from profits by placing inventories on a LIFO basis. ${ }^{5}$ Under LIFO, withdrawals from inventories are valued at the price last paid for inventoried items. Unless firms are closing out a line of business by selling inventories of finished goods, there are no holding gains. The U.S. is unique among industrial countries in permitting firms the choice of LIFO and several historical-cost accounting systems on condition that the same system is used in tax and financial books. Since historical cost systems such as first-in first-out (FIFO) inflate profits during inflations, they can liven up a stockholders' report, but LIFO clearly lightens the tax burden.

It is a continuing puzzle that most firms prefer non-LIFO methods. In 1982 , only 37 per cent of manufacturing firms reported using LIFO in the Census of Manufactures (U.S. Department of Commerce, Bureau of the Census 1986, Table 2-3c). Applying the average effective tax rate on operating surplus of 
41 per cent (Holland 1984, Table 1-6) in 1981 to the IVA for nonfinancial corporations of $-\$ 24.2$ billion, firms paid an excess tax on FIFO-type profits of about $\$ 10$ billion. Why almost two-thirds of the firms would make such a gift to the U.S. Treasury is a mystery. Two hypotheses are that managers fear the stockholders' response to lower reported profits upon switching to LIFO and that managers' bonuses are tied to reported profits (Bulow and Shoven, 1982).

Holding gains. The IVA effectively excludes holding gains on inventories from capital income, but studies of macroeconomic profitability have not uniformly accepted this treatment of holding gains. Shoven and Bulow $(1975,1976)$ propose adoption of Haig-Simons income through what they call purchasing porver accrual accounting; real capital gains, realized and accrued, on both net financial liabilities and physical assets count as profit.6 They also report a parallel set of books based on capital maintenance income, which includes holding gains on net financial liabilities. To convey an appreciation of the orders of magnitude involved, the three measures of before-tax nonfinancial corporate profits for 1974 are displayed below (in billions of dollars):

NIPA Profits with IVA and CCAdj

$$
60.2
$$

Capital Maintenance 89.9
Purchasing Power Accrual

169.3

SOURCE: Bulow and Shoven (1982, Table 11.2).

How should studies of macroeconomic profitability treat holding gains? I take up each type of gain as they affect the 
measures above from left to right.

Capital maintenance income includes holding gains from the effects of inflation on net financial liabilities. Because corporations are net debtors, inflation erodes the value of their liabilities, transferring income from the corporation's creditors. The principle that holding gains on net liabilities redistribute capital income rather than change' the amount of capital income produced justifies the use of net operating surplus (i.e. including net interest payments in capital income) in studies of macroeconomic profitability.

Consider the effects of inflation on the balance sheets and income statements of the corporate sector and its creditors, assuming corporations have a long-term bond outstanding with a par value of $\$ 1000$, and that their operating surplus is divided between $\$ 200$ retained earnings and a $\$ 100$ coupon on the bond. If inflation should rise from zero to five per cent, the capital accounts would record a $\$ 50$ holding gain for corporations and equivalent loss for their creditors. Thus, under capital maintenance income, corporations would experience income of $\$ 200$ plus the $\$ 50$ holding gain, while creditors would experience income of $\$ 100$ minus the $\$ 50$ loss. The operating surplus would be unchanged; $\$ 250$ plus $\$ 50$ equals $\$ 300$ as before.

Most researchers have accepted the NIPA practice of including imputed interest received in measuring net interest paid. Imputed interest overcomes the following problem that financial intermediaries cause in national accounts; see Ruggles 
and Ruggles (1956, pp. 60-64) for a full explanation. An established accounting practice for value added in an industry is to add up the income originating in that industry: compensation, dividends paid, retained earnings, plus net interest paid. Banks receive substantially more interest than they pay (otherwise they would fold), so to avoid negative value added in the banking industries, national income accountants impute interest payments. Depositors of the banks receive imputed interest, which returns in toto to the banks as a payment for banking services. This fictitious transaction reduced the gross domestic product originating in the nonfinancial corporate sector by about 24 billion dollars in 1985. Since imputed interest represents an ex post adjustment not reflected in any actual cash transaction, I calculate operating surpluses and rates of return below entirely on the basis of monetary interest. 7 The procedures change the levels of the rate of profit but not its trends.

Shoven and Bulow's purchasing power accrual income also includes real accrued holding gains on physical assets. Researchers have not achieved a clear consensus on the treatment of such gains; consult Holland and Myers $(1979,1984)$ or the separate studies of profitability in nine countries in Holland (1984) for examples of the variety of ways the issue is handled. I have found no instance in which a substantive conclusion about movements in profitability has been said to hang on this issue. Because holding gains can only redistribute wealth among accounting units in society without creating any new wealth, it 
can be argued that they should be excluded from capital income in studies of macroeconomic profitability, but see Eisner (1980) for an opposing viewpoint.

In measuring profitability below, I adopt a capital maintenance concept of income, and measure profitability on reproducible physical assets and monetary assets. In the tradition of Ricardo, Marx, Von Neumann, and Sraffa, the capitalist economy is conceived as a system in which commodities are produced by means of commodities; it is a self-reproducing system. The rate of profit measures the ability of the system to produce an economic surplus relative to its own-input requirements and in some models, notably Von Neumann's growth model, the rate of profit represents the maximum rate of expansion of the system. From this theoretical perspective, with its emphasis on profitability as a determinant of capital accumulation, nonreproducible inputs like land are not relevant to macroeconomic profitability however important they may be to individual units of capital. Moreover, as capital must adopt a succession of forms, from money capital to commodity inputs to commodity outputs, it is necessary at any given point in time to include these diverse forms by incorporating inventories, fixed capital, and monetary assets in measures of profitability (see Foley 1986A). Finally, the realized holding gains on net financial liabilitics associated with inflation need to be recognized as capital income at the macroeconomic level for reasons explained above, and this is accomplished by using 
operating surplus as suggested by the Pigou-Marshall concept of income.

Accounting rates of return. It is clear that the internal rate of return of the investment projects in operation constitutes the appropriate measure of macroeconomic profitability. However, this is rarely known ex post, and. researchers have to settle for an accounting rate of return equal to current accounting income (defined in various ways as will be seen) divided by capital stock estimated using an accounting system that does not accurately reflect economic depreciation. Accounting rates and internal rates only correspond under restrictive conditions. The net accounting rate equals net operating surplus divided by net capital stock; for the gross accounting rate, substitute the word gross into the foregoing. Feldstein and summers (1977) show that if gross profits on capital stock decay at a constant exponential rate, then the net accounting rate of return will exactly coincide with the internal rate of return if net capital stock is calculated by a perpetual inventory method that deducts depreciation expense at that rate of decay and adds investment continuously. If the capital stock decays like a light bulb, instantaneously at the end of its service life (sometimes called the "one hoss shay" case), then gross accounting rates of return and the internal rate will coincide for long-lived assets. The gross capital stock is calculated using a perpetual inventory method that deducts items at the end of their service lives. In either case it is possible 
to calculate the internal rate from an accounting rate by using a rate of depreciation that corresponds to economic depreciation.

The difficulty is that depreciation is typically calculated on a straight-line basis in national income accounts, even when this may not correspond to the actual pattern of economic depreciation. 8 Under this system, the gross accounting rate may actually be superior to the net accounting rate as an approximation of the internal rate according to the following argument of Hill (1979, Ch. 3). Consider first a balanced set of projects, for which new entries equal discards; this assumes zero growth of capital, and an equal number of projects of every age. In the one hoss shay example, the gross rate of return on a balanced set of projects approaches the internal rate as the service life of the representative project increases, but the net rate approaches a value twice the internal rate, illustrating again that the gross rate can give a better approximation of the internal rate when depreciation actually occurs through the discarding of burnt out "light bulbs."

Under more realistic conditions, it becomes difficult to say much about the relationship between accounting and internal rates of return. If the stream of gross profits is declining, due to the effects of physical wear and tear on machinery or to the effects of technological obsolescence, the effect of stacking returns closer to the beginning of a project will tend to raise the internal rate. If we assume that the sum of the gross profits remains fixed, but that they are concentrated in the 
early years of the project, then neither the gross nor the net rate will be affected but the internal rate will be raised, and it is impossible to say which accounting rate will lie closer to the internal rate. The conclusion Hill draws from all this is simply that "there is no justification for ignoring the valuable information provided by the average gross rate"(p. 66).

The fact that in practice neither Hill nor Feldstein and Summers nor I (in Figure 1 below) find very large differences between gross and net accounting rates would seem to strengthen this conclusion, whose practical importance lies in doing away with the need to calculate economic depreciation to estimate the rate of return. It is interesting to note that in Figure 1 the gross rate has declined more slowly than the net rate. Could this fact be consistent with Hill's finding that under the conditions described above (no growth, a balanced set of projects, and declining gross profits), the gross rate is a decreasing function of service life while the net rate is an increasing function? In the U.S., a secular shift from investment in structures to investment in equipment has probably reduced the service life of the representative project in the nonfinancial corporate sector.

The similarity between gross and net accounting rates of return does not validate the use of either, however, as the following quotations (which refer specifically to the net accounting rate) from prominent sources in the literature make clear: 
"...as an indication of the realized rate of return the accountant's rate of profit is greatly influenced by irrelevant factors, even under ideal conditions." (Harcourt 1965, p. 80) [note: Harcourt assumes a Golden Age in which the realized rate of return is equal to the internal rate of return.]

"...accounting rates of return, even if properly and consistently measured, provide almost no information about economic rates of return." (Fisher and McGowen 1983, p. 82)

Much of this literature focuses on comparisons across firms and industries rather than across time for broad macroeconomic aggregates. Fisher and McGowen's argument, for instance, was used to defend IBM's rather high accounting rate of return in anti-trust litigation. 9 It is clear from this literature that differences in service lives, in time profiles of returns, or in growth rates all create rather arbitrary divergences between net accounting rates and internal rates of return.10 It is somewhat unsettling that these, conditions are all likely to be changing over the long stretches of historical time typically examined in studies of macroeconomic profitability, suggesting the need for further research into the practical importance of the objections voiced above. 


\section{Studies of Macroeconomic Profitability}

\footnotetext{
"One of my gripes is that everybody in this business rolls their own cyclical adjustment method with every paper. I wish we could somehow standardize on one and use it consistently."

Robert Solow in Bosworth (1982, p. 319)
}

Long-run growth models make predictions about movements in the share and rate of profit over historical time, but profitability may mirror cyclical factors having only a remote relationship to long-run forces. Short-run reductions in output, for example, raise unit costs because overhead expenses (including overhead labor costs) are spread over fewer units. If firms do not raise their mark-up sufficiently (and evidence suggests they do not), profits will be squeezed and unsqueezed through the normal operation of the business cycle. There may, of course, be more complex relationships involving profits in the cycle, but the tendency for unit costs to move anti-cyclically is among the most universally agreed upon. An established method for separating cyclical and secular movements in profitability uses regression analysis to estimate the rate of return that would exist at normal levels of capacity utilization.l 1

Cyclical adjustment. The major studies of profitability in the U.S.12 and other industrial countries using regression analysis are arranged in Tables 3 and 5 . Both of these tables report a representative finding about the nature of historical movements in profitability but do not necessarily convey the full breadth of authors' findings which are often contained in a 
battery of regression results. The second and third columns show the coverage of the study. Most researchers in the U.S. have chosen the nonfinancial corporate sector, while most of the studies of other industrial countries focus on manufacturing. The fourth column describes the measure of profitability. The distinction between before and after-tax profitability turns out to be one that matters substantively. The remaining columns are explained below.

My purpose is to lay before the reader the full array of methods, choices of data, and principal results about the pattern of historical movements in profitability, beginning with the methodology of cyclically adjusting profitability.

The hypothesis of mark-up pricing over standard or normal unit costs underlies the cyclical adjustment of profitability. Simply put, firms set prices by marking up their normal unit costs. Normal costs are tied to a normal or trend level of output rather than the actual level, which fluctuates over the business cycle. Mark-up pricing is fundamentally an hypothesis about how prices change in response to changes in costs rather than a complete theory of prices. This hypothesis has a long and venerable history, and several versions of it exist.13

In the strictest version, the mark-up is fixed by long-run considerations, and is insensitive to product or labor demand. Such absolute price stickiness remains among the more controversial issues in economics.14 Disagreement about how inclusive to make normal unit costs also defines different 
schools of thought, but it has not had a major impact on the profitability literature. One exception is Nordhaus, who experiments with a variety of mark-up models. Of six alternatives on a spectrum from least to most inclusive of different costs, Nordhaus finds the simplest model (mark-up over normal unit labor costs, including salaricul laborl tracks the data best (1974, p. 188-90).

For ease of exposition, consider an economy having only labor costs, assuming intermediate goods wash out at the aggregate level. The mark-up pricing equation is:

$$
p=(1+m) w\left(L_{n} / X_{n}\right)
$$

where $m$ represents the mark-up, $p$ and $w$ represent price and money wage, $L$ and $X$ are labor and output per period, and a subscript $n$ indicates the normal level of a variable.

The share of net operating surplus fluctuates with the level of effective demand to the extent that actual unit costs deviate from their normal values over the business cycle. One of the best established facts about costs is the existence of short-run increasing returns to labor. 15 Increased employment typically decreases unit labor requirements, so we can write:

$$
L=a_{0}+a_{i}\left(X / X_{n}\right) \quad a_{i}>0
$$

The operating surplus is simply the residual remaining out of receipts after labor costs, pX - wL. Substituting equations 2 and 3 into this equation we obtain the following expression:

$$
\text { NOS }=-w_{0}+w\left[(1+m) L_{n}-a_{1}\right]\left(X / X_{n}\right)
$$

The rate of return is simply the ratio of operating surplus 
to the aggregate capital stock at current prices, pK, and can be written, after some manipulation, as:

$$
r=b_{0}+b_{1}\left(x / x_{n}\right) \quad b_{1}>0
$$

where bo and bl group terms for simplicity.16 This equation for the cyclical behavior of the rate of profit is essentially the mark-up pricing equation in reduced form.

Corresponding to equations 4 and 5 are techniques for cyclically adjusting profits in order to identify trends and shifts. Corresponding to equation 4 is what $I$ will call the mark-up pricing method which reconstructs the time series for normal costs and plugs these into equation 2 to predict prices or equation 4 to predict profits. Comparing the predicted to the actual values of prices or profits is the modus operandi of the mark-up pricing method. Obviously actual mark-up models are more complex (for example, fixed capital, from which I abstract, plays an important role in changes in average total cost over the cycle) but this exposition does convey the flavor of what they do.

Corresponding to equation 5 is the method of regression analysis used by most researchers in the field. Unlike the markup pricing method in which a constant mark-up is imposed on the data, the regression approach permits researchers to relax the constant mark-up assumption over historical time. By plugging in normal or full capacity levels of the variables in their estimated regression equation, or by correcting the raw data for capacity utilization by using the estimate of its effect from 
equation 5 , they generate cyclically adjusted time series of the rate of profit.

As column five of Table 3 makes clear, researchers have cautiously tried a variety of instruments to control for the cycle, ranging from the Federal Reserve Board's capacity utilization index for manufacturing, to estimates of the gap between actual and potential GNP. As it is customary for researchers to report their results over a range of such instruments, since no single measure of capacity utilization is perfectly suited to the task at hand, it is possible to state that the choice of cyclical control has not been argued to affect substantive conclusions about the statistical significance of trends in profitability in the studies surveyed here. Some of the studies go beyond mere cyclical control by including additional explanatory variables like the inflation rate in the plain-vanilla regression equation.

The real differences lie in the specification of the pattern of trends. Three methods of trend analysis are used, which I call simple trend, trend/shift, and trends-with-bends. The following equations are representative of these three methods: $r=b_{0}+b_{1} C U+b_{2} t \quad$ Simple trend

$$
\begin{array}{lll}
r=b_{0}+b_{1} C U+b_{2} t+b_{3} D(Y E A R S) & \text { Trend/shift } \\
r=b_{0}+b_{1} C U+b_{2} t+b_{3} D(Y E A R S) t & \text { Trends } w / \text { bends }
\end{array}
$$

In these equations, $C U$ represents some measure of capacity utilization, $t$ a time trend, D(YEARS) a dummy variable equal to unity over some time segment and zero everywhere else, and $t$ ' a 
time trend covering the dummy interval. Thus, D(YEARS)t represents a trend which operates only over that time segment, and is zero everywhere else. Table 3 reports the composite trend, which is the sum of trend coefficients operative in a given period, rather than the original coefficients. Obviously, it is possible to include several dummy variables, several trend segments, and to mix the trend/shift and trends-with-bends approach.

A word of warning on the subject of significance: statistical significance should not be confused with economic significance. A large trend term whose standard error of estimate is also large (the condition which defines statistical insignificance) can certainly reflect an economically important process, while a very small and significant coefficient may be virtually meaningless in the larger scheme of things. In the studies under review, statistical significance turns out to be a convenient way to summarize whether a coefficient estimate is large and troublesome or small and ignorable.17 For example, Holland and Myers (1979) report that without a cyclical control, the trend coefficient on before-tax profitability from 1946-76 is -0.19 , with a standard error of 0.08 ; statistically significant by conventional standards. When a cyclical control is added the trend coefficient falls to -0.11 , with a standard error of 0.08 ; insignificant by virtue of the reduced estimate value. Studies of profitability in the U.S. Readers may find it useful to refer to Figures 1 and 2 , which show the before and 
after-tax rates of profit for U.S. nonfinancial corporations from 1948-1985. The methodology follows that used widely in the literature except for the exclusion of land from the denominator and imputed interest from the numerator, and the inclusion of monetary assets in the denominator. These differences and the recent revisions in the U.S. national income and product accounts reviewed in the previous section affect the details but not the overall impression conveyed graphically. The before-tax rate of profit has a clear downward tendency, with a large bulge in the mid-1960's. The after-tax rate of profit has no clear tendency, but also has a large bulge in the mid-1960's. Researchers have asked whether these tendencies survive cyclical adjustments, and have given a surprisingly heterogeneous array of responses.

Accounts of movements in the before-tax rate of profit vary. Feldstein and Summers and Feldstein et al. (refer to Table 3 for citation dates) identify a distinct once-for-all downward shift occurring around 1970 and depressing the rate of return for the decade thereafter by from 1.3 to 2.0 percentage points. Overlaid on this discrete shift, the trend is generally nonsignificant and is found to be positive in Feldstein et al. Other researchers using slightly different cyclical controls also find a shift after 1970. The overlaid trend is not clear; Grimm finds a significant positive trend, Holland and Myers a nonsignificant negative trend, and Allman reports a significant negative trend. Lovell, using the trends-with-bends technique and the log of the profit rate rather than its level, finds a declining trend before 
1965, a more steeply declining trend from 1965 to 1970 , and a rising trend thereafter.

By these accounts, the before-tax rate of return was abnormally low in the early 1970's. Liebling argues that the 1960's witnessed abnormally high profitability owing to a confluence of specially favorable circumstances. and includes a dumny variable for 1962-1968.18 The overall trend coefficient then becomes significant and negative. In other regressions not covered in the table, Liebling finds that those same results obtain when a dummy for $1970-75$ is also included in the regression equation; the dummy for $1970-75$ is negative, nonsignificant, and about half the size of similar shift terms uncovered by Feldstein and summers, while the trend term remains negative and significant. It may be facetiously concluded that researchers have agreed to disagree about whether the tide is coming in or going out.

The general impression that profitability rose to unusual peaks in the mid-1960s and fell to unusual troughs in the $1970 \mathrm{~s}$ is corroborated by the two studies using the mark-up pricing method. Nordhaus compares the actual level of before-tax profits to the level predicted by his mark-up model, and finds underpredictions from about 1961 to 1967 , and overpredictions from 1969 to 1973 (Nordhaus 1974, Table 8, p. 190). Clark finds more or less the same pattern (Clark 1984, Figure 3, p 159), but also that the cyclically adjusted before-tax profit share rose in the $1980^{\prime} \mathrm{s}$. 
There is a clearer consensus that the after-tax rate of profit has no full-period trend. Researchers using the trendswith-bends technique agree on a rising trend before 1965 and a declining trend from 1965 to 1970 , but disagree about whether a rising or falling trend marks the 1970's; compare Kopke and Love11. Researchers using trend/shift analysis find a weak rising trend, with a negative shift in the $1970 \mathrm{~s}$, but the statistical significance of each of the relevant coefficients varies across studies; compare Grimm to Holland and Myers. Liebling posits an upward shift in the 1962-68 period, which is significant and positive as in his before-tax equations.

Studies of other industrial countries. Table 4 shows the before and after-tax net rate of profit on plant, equipment, and inventories in the manufacturing sectors of nine countries from the Holland (1984) studies. There is a perceptible tendency for rates of return to be lower in the $1970^{\prime} \mathrm{s}$ than in previous periods. As Holland notes (pp. 8-9), declines are more pronounced for before-tax rates of return than for after-tax rates of return.

Most of the regression analyses reported in Table 5 use the simple trend method. Significant declining trends in cyclically adjusted before-tax rates of profit are found for the manufacturing sector of United Kingdom, Austria, Finland, Canada, Germany, and the corporate sector of Sweden. Significant declining trends in after-tax rates of profit in manufacturing are found only for Austria, Canada and Germany. The lone study 
which uses the trend/shift technique fwith a dummy variable covering 1969-73) finds a significant negative shift in both before and after-tax profitability in the United Kingdom, and a significant positive shift in before and after-tax profitability in France.

What have we learned post-Nordhaus? A safe conclusion from studies of the U.S. is that before-tax profitability was low in the $1970 \mathrm{~s}$ compared to previous periods. There is little agreement about long term trends in before-tax profitability in the U.S., but some agreement that after-tax profitability is essentially trendless. By the benchmark of the $1960 \mathrm{~s}$, both species of profitability declined into the 1970 s, but it is hard to ignore the unusual nature of the $1960 \mathrm{~s}$, a leitmotif that reappears in this paper. Declining profitability has not been confined to the U.S., although researchers have reached the same Scotch verdict on whether declines reflect long term trends or cyclical shocks. Since these declines coincide with a period of worldwide economic stagnation, they certainly justify more intensive theoretical scrutiny.

The wide variety of impressions conveyed by different researchers about long-term trends in the before-tax rate of profit in the U.S. testifies to the difficulty of using econometric techniques to identify objective properties of economic data. It is clear, for instance, that where one chooses to locate shifts influences the results with respect to trends. Another difficulty resides in the restrictive assumptions 
underlying the regression analysis itself. The implicit assumption behind the use of the cycle-trend regression approach is that exogenous shocks to aggregate demand determine the level of profits in the short run and that long-run influences are captured by the trend terms. First, one is inclined to ask what are the causes of the movements revealed by the trend terms. second, one is inclined to ask what effects these changes in profitability might have on the operation of the economy, including how reduced profitability might affect the level of aggregate demand itself, for example through its retarding influence on capital accumulation. Some accounts which relate to these questions are discussed in the remainder of this paper.

Decomposition of profitability. An alternative framework for analyzing movements in profitability developed by weisskopf (1979) provides a convenient bridge to the discussion in the next section of causes of declining profitability.

Weisskopf identifies three possible explanatory factors for downward movements in profitability: the relative strength of labor, the level of aggregate demand, and the average productivity of capital. Each of these explanatory factors gives rise to an alternative hypothesis about the source of declining profitability. The rising strength of labor hypothesis asserts that workers' ability to win real wage increases in excess of productivity growth during periods of tight labor markets explains declining profit rates. The demand failure hypothesis asserts a tendency for demand to stagnate and for excess capacity 
to drag down the rate of profit through the mechanism by now familiar to the reader. The declining productivity of capital hypothesis asserts a long-run tendency for capital accumulation to depress average capital productivity. 19 Weisskopf suggests the following growth accounting framework in which the relative empirical importance of each of these three explanatory factors can be evaluated:

$$
r=(\mathrm{NOS} / \mathrm{pK})=(\mathrm{NOS} / \mathrm{VA})(\mathrm{VA} / \mathrm{VAf})(\mathrm{VAr} / \mathrm{pK})
$$

$$
\dot{r}=(N O S / V A)+(V A / V A f)+\left(V_{f} \dot{f} / \mathrm{pK}\right)
$$

$A$ dot over a variable indicates its exponential rate of growth, VA represents value added, VAf represents the potential or full capacity level of value added, and operating surplus is before tax. Equation 7 permits a decomposition that corresponds to the elements of the three hypotheses. The first hypothesis implies a declining profit share, the second hypothesis implies a declining rate of capacity utilization and the third hypothesis implies a decline in full employment capital productivity.

Weisskopf focusses on two questions. What role does each of these factors play in explaining long-term movements in the rate of profit? What role does each factor play in explaining movements in the rate of profit over the typical business cycle?

Table 6 shows the results which address the first question from Weisskopf's study of the U.S. nonfinancial corporate sector, and two studies in the same tradition. Declines in capacity utilization account for little of the full-period declines in profitability in any of these studies. This, of course, 
contradicts the findings of those researchers surveyed above who argue that declines in profitability can be explained by variations in aggregate demand. All three studies find that the decline in the profit share accounts for most of the declines in profitability. Finally, while weisskopf finds that declining capital productivity was an insignificant factor both other studies find declining capital productivity played a role in accounting for declines in the rate of profit.

Weisskopf develops a more complex version of the same growth accounting framework in order to address two issues. First, does the fall in the profit share reflect a real change in distributional relations between capital and labor or does it merely reflect the natural tendency for the profit share to track the business cycle owing to the existence of overhead labor and labor hoarding. Second, if there has been a real change in distributional relations, does it reflect a rise in labor's offensive ("ability of the working class to achieve real wage gains more rapid than productivity increases") or defensive ("workers' ability to pass on to capitalists a disproportionate share of the real income loss resulting from adverse relative price changes") strength (Weisskopf 1979, p. 372).

Weisskopf finds that even after accounting for capacity utilization and overhead labor effects, substantial shifts in the profit share occurred over the full period. His conclusion is that

$$
\begin{aligned}
& " \text {. the long-run and cycle-to-cycle increases in labour } \\
& \text { strength were predominately defensive in nature. The basic }
\end{aligned}
$$


reason for the downward trend in the rate of profit from 1949 to 1975 was an increasingly serious deterioration in the terms of trade of the NFCB [nonfinancial corporate business] sector, whose negative impact on real sectoral income was absorbed to a proportionately larger extent by profits than by wages."(pp. 372-373)

The same accounting framework is applied to movements in the rate of profit over the business cycle, where it is clear the rate of capacity utilization does not track the rate of profit as symmetrically as the regression analyses surveyed above implicitly assume. 20 The rate and share of profits generally lead capacity utilization. Hahnel and Sherman (1982, Table 5) observe that on average over the post-war period, the National Bureau of Economic Research cycle peak was preceded by the peak in the share of profit by 8.8 quarters, by the peak in the rate of profit by 7.3 quarters, and by the peak in the level of capacity utilization by 3.8 quarters.

Weisskopf divides the cycle into three distinct phases for analytic purposes: phase A, after the cycle trough but before the profit rate peak; phase $B$, after the profit rate peak but before the cycle peak; and phase $C$, from cycle peak to cycle trough. During phases $A$ and $C$, changes in capacity utilization and their now-familiar effects on productivity play the major role in regulating profits. But in the late expansion, phase $B$, demand, output, and productive capacity grow at very much the same rate, and it is possible, I believe, to identify patterns in this phase that are effectively independent of the "noise" created by fluctuations in capacity utilization.

The data relating to phase $B$ of the cycle from three studies 
are shown in Table 7 . Changes in capacity utilization indeed play a minor role in accounting for changes in profitability in phase $B$ of the average cycle. The consistency with which changes in the profit share account for declines in the profit rate suggests that the assumption of a constant mark-up over normal unit costs is misleading. To the extent one is inclined to believe that actual costs closely approximate normal costs during the $B$ phase, changes in the profit share reflect changes in the mark-up in this phase of the cycle.21 How, after all, do firms know what their normal costs are but by observing their actual costs during a period of normalcy?

Argument about the ability of workers to win real wage increases under favorable labor market conditions has been going on since Keynes and Kalecki first proposed that real wages are determined in the product market by firms' pricing policies. The patterns uncovered by Weisskopf and others represent a challenge to this way of thinking, because they suggest that the mark-up is actually determined by some kind of bargaining process probably, I suspect, involving both firms and workers in the labor market and firms and customers in the product market. Taylor (1985) and Marglin $(1984 \mathrm{~A}, 1984 \mathrm{~B})$ incorporate the contest in the labor market into the supply side of their theoretical models.

A variable mark-up suggests some natural modifications to the regression approach above. On the supply side, it may be advisable to use dummy or proxy variables to model events in phase $B$. On the demand side, mark-up variability raises the 
question of the adequacy of using the level of demand in explaining short-term movements in profitability.

The volume of after-tax profits realized in a short period equals the sum of rentier consumption, investment, the budget deficit and the trade surplus (assuming zero saving out of wages) according to Kalecki's profit identity (1971, pp. 78-82), familiar among neo-Keynesian economists. Now, if capacity utilization increases exclusively because of the demand effects of a real wage increase (reduced mark-up), it will certainly have a different effect on total profits than the equivalent increase in utilization brought about by an investment boom with constant real wages. Some account of the composition of demand may have a place in explaining movements in profitability. One suggestion might be to embed the study of cyclical movements in profitability in a more fully specified model of aggregate demand and supply, such as a version of the previously mentioned models of Taylor or Marglin. 


\section{Explanations of Declining Profitability}

"In my view, it would be worth studying growth models that would accommodate various degrees of profitability. Discussing them should help us to understand some features of sustained unemployment in slowly growing economies, in which a lack of profitability prevents expansion of productive capacities."

$$
\text { Edmond Malinvaud (1984, p. 61). }
$$

I now turn to explanations of the causes and consequences of low profitability in the 1970 s. Causes proposed range from diminishing returns to capital induced by a low cost of funds; intensified international competition; profit squeezes driven by rising real wages, flagging productivity growth, rising raw material prices, or some combination thereof; declining average capital productivity; and changes in effective tax rates. The "stagnationist" school of neo-Marxian and neo-Keynesian economists, which regards low profitability as a consequence of the stagnation of aggregate demand, is somewhat underrepresented in my discussion; refer to steindl (1979) for elaboration. To illustrate the range of opinions $I$ do discuss in detail, note that the first explanation implies that profitability fell because of an abundance of capital, while many profit squeeze theorists perceive a declining rate of capital accumulation because of reduced profitability.

Cost of funds. In a seminal contribution, Nordhaus (1974) argues that a declining cost of funds 22 induced an increase in capital deepening: firms chose to adopt progressively less profitable investment projects. The cost of funds ordinarily 
contains a premium to cover nondiversifiable risk. Nordhaus argues that as memories of the Great Depression faded, investors reduced the risk premium. More recently, Bosworth (1982) proposes that accelerated inflation in the 1970 s drove down the real rate of interest, reducing the cost of funds. 23

Both hypotheses attribute reduced profitability to an abundance of capital relative to labor. Indeed, Bosworth argues in the context of an extended refutation of the "capital scarcity thesis" that insufficient after-tax profitability has reduced the incentive to save and invest in the U.S.

It is difficult to evaluate the low cost of funds hypothesis because the cost of funds is not observable. Firms raise funds in equity and bond markets, and the cost of funds reflects the optimal mix of debt and equity, the effects of taxes, and the effects of expected inflation, all challenging to quantify. Attempts to measure the cost of funds have led to divergent estimates, and Bosworth himself, in a later article (1985, pp. 19-27) demonstrates that the differences can be substantial. Other researchers (Corcoran 1977, p. 5; Kopke 1978; Holland and Myers 1979) who compare their estimates of the cost of funds to the rate of return, however, generally find that tho decline in the rate of profit was not reflected in a lower cost of funds in the 1970s. Holland and Myers (1979), for instance, report that "the decline in corporate real profitability over the last decade [1966-76] has not been matched by a corresponding decline in the real opportunity cost of capital [cost of funds]"(p. 147). 
One way of approaching the link between profitability and the cost of funds is through Tobin's $q$, the ratio of the market value of a firm (i.e. the sum of its debt and equity at market value) to the replacement cost of the firm's tangible assets. Because the market value of a firm is the present discounted value of investors' expectations of its future earnings stream, Tobin's $q$ can be expressed as the ratio of the expected profit rate to the cost of funds (i.e. the discount rate of investors) under some conditions (Tobin and Brainard 1977, p. 244). To the extent that current profitability is an indicator of future profitability, movements in the q ratio can then be interpreted in terms of the ratio of the rate of return to the cost of funds. The Nordhaus-Bosworth explanation cast into q-theoretic terms predicts that $q$ will fluctuate around its long-run equilibrium value, equal to unity under restrictive conditions. 24 In equilibrium, the cost of funds and rate of profit should rise and fall pari passu.

Studies of $q$ in the U.S. show rising values until 1965, and then falling values into the $1970 \mathrm{~s}$, suggesting that the rate of return fell by more than the cost of funds in the later period. Table 8 displays some average values of $q$, the rate of return on nonfinancial corporate assets, and the implied discount rate. Like measures of the cost of funds, measures of $q$ vary widely. The procedure I used does not mark corporate debt to market, but does use the market values of equity from the Flow of Funds Accounts. Nonetheless, in its movements, it resembles the 
typical finding of rising values up until the mid 1960s, then falling values through the 1970s. The effects on $q$ of the bull market of the $1980 \mathrm{~s}$ are somewhat obscured by the use of five-year averages in Table 8 . For more carefully constructed measures of $q$, see Holland and Myers (1984) and Von Furstenberg (1977). It is clear that the decline in $q$ in my data from 1966-70 to 1971-75 was mainly due to a decline in profitability, and that the continued decline to 1976-80 was due to a combination of lower profitability and a higher cost of funds. 25 Impressions about movements in $q$ for other countries can be found in Holland (1984) and Chan-Lee (1986).

Import competition. Kaldor, commenting on Nordhaus's 1974 paper (in Nordhaus 1974, p. 209-210) gainsays the capital deepening explanation, and in its place, offers an explanation based on import penetration of oligopolistic markets under entrydeterring price leadership.

Increasing world trade (as a share of world output) is a persistent feature of the post-war period. If market structures in internationally traded goods were oligopolistic at the beginning of the period, a general increase in world trade would raise the degree of effective competition, and cut into the oligopoly element of the mark-up. ${ }^{26}$ This story fits the facts in two respects. First, intra-industry trade has grown as a share of trade between industrial nations (Aquino 1978). Second, the more pronounced decline in manufacturing profitability than aggregate business sector profitability visible in Table 9 may 
reflect the greater proportion of internationally traded goods in the manufacturing sector; see also Holland (1984, p. 25$)$.

The explanation of globally declining profitability as the epiphenomenon of rising world trade suffers two flaws. First, lower mark-ups from greater effective competition may not reduce profitability; Dutt (1984) presents the "stagnationist" argument that an increase in product market competition raises the rate of profit because of the accelerator effects on investment of higher real wages. Recall that greater investment realizes greater profits through Kalecki's profit identity. Second, international competition probably reduces labor's ability to achieve higher real wages under some conditions -- think of the U.S. in the 1980 s -- thereby raising the interesting question of the determinants of which effect (mark-up raising or lowering) prevails.

Studies of the mark-up pricing hypothesis have produced a major puzzle. Coutts et al. (1978) find the residuals between actual prices and the prices predicted by their model of $U . K$. manufacturing are uncorrelated with import prices, as if foreign competition has no effect on mark-ups.

Profit squeezes. Sylos-Labini (1979A) argues that because import prices are already included in the standard costs coutts et al. estimate, the results they obtain "would no longer appear paradoxical"(p. 162). For Sylos-Labini, the issue is important because he argues that foreign competition has been the "main reason" (p. 161) for declining profit shares. Sylos-Labini 
(1979B) elaborates: the upward pressures of wages and raw material prices against the limitations imposed by foreign competition on product prices account for a declining tendency in the mark-up.

International competition is an important ingredient in explanations of declining profitability based on rising labor strength or wage costs. A long-standing proposition associated with Keynes and Kalecki is that workers can effectively bargain only over the money wage. Under mark-up pricing, a general increase in wage costs will be fully passed through to higher prices, leaving real wages unchanged (unless there is a raw material sector willing to take the hit). Product demand is assumed to stay constant--there are no wealth effects--which permits firms to pass through costs without fear of losing customers. Glyn and Sutcliffe (1972) suggest that foreign competition will inhibit firms from passing through their cost increases, and that in its presence, rising labor strength generates real distributional changes rather than mere inflation. 27 As noted above, the possibility that import competition can erode worker bargaining power must also be acknowledged.

Recent work in the Marxian profit squeeze tradition enriches the profit squeeze hypothesis in two ways. First, conflict over the intensity of labor and hence labor productivity is proposed as an additional source of rising unit labor costs. The intensity of labor, in turn, is hypothesized to reflect workers' 
individual or collective decisions about how much effort to provide, which they make by comparing the cost of losing their jobs (cost of job loss) with the benefits of shirking. For elaboration, see the empirical study of Weisskopf et al. (1983) or the theoretical model of Bowles (1985). Second, conflict over the conditions of production and distribution is situated in a broader institutional context that includes struggles over state policy, struggles between industrial and nonindustrial economies, and conflict between labor and capital. The concept of a social structure of accumulation sums up the institutional fabric; for more explanation, consult D. Gordon et al. (1982).

Social structures of accumulation are hypothesized to have a life cycle of their own, eventually outliving their usefulness in smoothing the path for capital accumulation. For example, postwar collective bargaining is sometimes described as an "accord" which initially fostered a high intensity of labor effort and a high rate of profitability, but eventually broke down under the efforts of both sides to escape its terms. When a social structure decays, an era of'low profitability and slow growth ensues, during which new institutional solutions are fashioned. Long waves of economic activity are reflections of waves of institutional innovation. The theory might be described as a kind of institutional version of Schumpeter's theory of capitalist development.

Bowles et al. (1986) derive an econometric model of aftertax nonfinancial corporate profitability in the post war U.S. 
economy inspired by the social structure of accumulation approach. This study is a companion to Weisskopf et al. (1983), in which the same three authors apply a similar framework to the slowdown in labor productivity after the mid 1960s. The flavor of their analysis is conveycd by the passage below. By decomposing changes in profitability using the actual values of the independent variables and estimated coefficients of their econometric model, Bowles et al, are able to conclude that, ". . the major source of profitability decline from 19591966 to 1966-1973 was the erosion of the labor accord--and the decline of the cost of job loss in particular. From 1966-1973 to 1973-1979, by contrast, declines in the utilization variables and in the international strength of United States capital were the major factors contributing to the fall in the profit rate"(1986, p. 154).

While it has been the hallmark of most neo-Marxian and many neo-Keynesian economists to advance explanations involving class conflict, these are by no means their exclusive property. A similar view of recent events differing in some details 28 is offered by mainstream economist Peter Clark:
". . Generally tight labor market conditions in the late 1960 s and early 1970s could have shifted the balance of power in favor of labor, cutting into capital's share. This new division of output prevailed until the determination to reduce inflation even at the risk of protracted high unemployment started moving the balance of power back toward capital in the 1980s. The mid-1970s downturn might have been ineffective in changing the climate for income-share determination because the recovery was relatively rapid. . Back-to-back recessions in the early 1980 s could have had more of an effect on the labor market climate, explaining the apparent rise in capital's share"(Clark 1983, p. 161).

In both views, economic slack is a policy response to rising labor strength.

Wolff (1986) also argues that the combination of declining 
productivity growth and rising labor compensation conspired to depress profitability in the early 1970s. He emphasizes upward pressure on labor costs exerted by the social rather than the private wage, and in particular by rising social security contributions, and regards the productivity slowdown as an exogenous event.

Wolff uses a sophisticated input-output framework to calculate the hypothetical general rate of profit that would exist if all industries earned the same rate of profit; i.e. to reconstruct the price system so that it represents an economy in a state of long-run equilibrium. 29 The actual average profit rate will generally differ from the hypothetical general rate. Wolff reports an interesting counterfactual exercise, reproduced below for the years of decline in the rate of profit. Reading across rows shows the change in the general rate of profit that would occur if real per worker consumption remained constant at that year's value, and the technology changed. For example, reading across row 1 , the matrices of circulating and fixed capital and the vector of direct labor requirements are actual values, while the vector of per worker consumption requirements stays at its 1967 level. Reading down columns, technology stays constant and consumption changes. Thus reading down the main diagonal shows the actual change in the general rate of profit. 
Constant Technology

Constant

Consumption

1967

1976

1967

$16.8 \%$

$14.7 \%$

1976

12.9

11.7

Source: Wolff (1986, Table 7, p. 102)

Even if consumption per worker had remained stable from 1967 to 1976, changes in technology alone would have depressed the rate of profit. The possibility that technological change can reduce profitability is discussed further below. The rise in consumption per worker, which Wolff attributes to rising social security contributions (p. 104), brought the rate of return down further. 30

Bruno and Sachs (1985) combine increasing raw material prices, real wage rigidities, reduced investment and the productivity slowdown. Since I am concerned with their account of profitability, I focus on the supply side of their model.

The centerpiece of Bruno and Sachs' supply story is a three factor production function. Gross output, $Q$, is a function of capital, K, labor, $L$ and raw materials, N. To simplify exposition, they assume that the production function is "weakly separable" in the raw material input, so that it can be solved in stages: $Q=Q[G(K, L), N]$.

By the assumption of weak separability, increases in raw material prices create homothetic shifts in the factor price frontier (the dual of the production function) analytically equivalent to Hicks-neutral technical regress. The factor price 
frontier represents the set of maximal marginal products permitted by the available technologies and existing raw material prices, or $F\left[\left(f\left(W_{q}, R\right), P_{m}\right]=0\right.$, where $W_{q}, R$, and $P_{m}$ represent the product wage, profit rate, and relative price of materials. It is convex to the origin in product wage-profit rate space, by virtue of well-behaved neoclassical technology. 31

With a given supply of capital and labor, both fully employed, and a raw material price shock, the factor price frontier shifts inward homothetically. Continued full employment requires that the product wage and rate of profit decline proportionately, so that the original capital-labor ratio will be maintained. If real wages are rigid, and technology is "puttyputty", firms substitute the given supply of capital for labor, so that employment falls short of full employment. This type of unemployment Bruno and Sachs call "classical unemployment", following Malinvaud's (1977) famous distinction between Keynesian and classical unemployment. ${ }^{32}$ Keynesian unemployment is represented by a position of the factor price frontier caused by insufficient aggregate demand.

Bruno and Sachs attempt to measure the contribution made by real wage rigidities, which they attribute to institutional wage setting practices like indexation, to total unemployment. The gap between actual product wages and the hypothetical product wage which would bring about full employment with the existing capital stock is called the "real wage gap" (p. 31). The wage gap plays an important role in their explanation of stagnation 
after 1973 .

Movements in the rate of profit are resolved into shifts in the factor price frontier due to the combined effects of technical progress and raw material price changes, and movements along the factor price frontier. The factor price frontiers for the manufacturing sectors of four countries (U.S., U.K., Germany, and Japan) are estimated assuming that the function $Q[G(K, L), N]$ exhibits a constant elasticity of substitution between raw materials and $G(K, L)$, that the function $G(K, L)$ is Cobb-Douglas (elasticity of substitution equal unity), that technical progress is Harrod-neutral, and of course, that constant returns to scale prevail.33 The general impression is that:

"until 1972 there was an upward movement in [product wages per efficiency unit of labor] more or less along a given FPF [factor price frontier], a clear shift to a new FPF after 1972, and movement down the new curve after 1973-74" (p. 52). [Movement down the new curve means lower product wages and higher rates of profit.]

In reference to the U.S., this conclusion supports FeldsteinSummers' contention that there was a downward shift in the rate of profit in the 1970 's due to the raw material price effect, but also indicates a downward drift in before-tax profitability owing to persistent product wage pressure from 1955 to 1972 . The framework of estimating the factor price frontier directly thus has much to recommend it, since it breaks movements in profitability down into their proximate causes rather than relying on hard-to-interpret trend terms as do the regression analyses discussed above. Further, as the factor price frontier is a tool of analysis familiar to neoclassical, neo-Keynesian, 
and neo-Marxian economists, the fact that it can be given empirical content should be encouraging to a broad range of economists.

Bruno and Sachs' macroeconomic story revolves around the interaction between the profit squeeze identified above, capital accumulation, and productivity growth. The following passage conveys the flavor of the analysis.
"In the late 1960 s and early 1970s, a real wage explosion (particularly in Europe and Japan) caused a major shift in income distribution away from profits and towards labor. Even before the oil shocks, therefore, many OECD countries faced a major problem of declining profitability and slowing growth. In the second phase real wages did not decelerate (outside of the United States) to make room for the raw material price increases, so the profit squeeze. intensified. In the third phase low profitability and rising unemployment slowed the rate of capital accumulation and productivity growth. Real wage increases were reduced, but so too was productivity growth, with the result that the excess of wages over full-employment productivity persisted into the early $1980 \mathrm{~s}^{\prime}(\mathrm{p} .167)$.
The last sentence throws the real wage gap into sharp relief. The passage also illustrates the thesis that real wages in the U.S. are less rigid than in other OECD countries (Sachs 1979). Bruno and Sachs regard the profit squeeze in the U.S. as less severe than elsewhere, and the U.S. economy as more "Keynesian" than others (p. 274).

In comparison with economists who regard declines in the cost of funds as the cause (through capital deepening) of lower profitability, Bruno and Sachs (pp. 23-26) regard the low real interest rates in the wake of the first OPEC price shock as a consequence of the profit squeeze. The world interest rate clears the market for world saving and investment. Saving is 
positively related to interest rates, and positively related to raw material prices if raw material producers' weighted marginal propensity to save exceeds the weighted marginal propensity to save of material importing countries. Investment is inversely related to real interest rates for familiar neoclassical reasons, and inversely related to permanent changes in raw material prices, since these reduce the future expected marginal product of capital (shift the factor price frontier in). Thus, the first OPEC price shock shifted the saving function up, the investment function down, (with $S$ and $I$ on the vertical axis) reducing investment and real interest rates simultaneously. 34

Investment and profitability. Bruno and Sachs's treatment of accumulation departs from the conventional neoclassical theory of investment in which firms target a desired stock of capital given by (with Cobb-Douglas technology):

$$
\mathrm{K}^{*}=(\mathrm{CY} / \mathrm{Z})
$$

where $C$ is the profit share, $Y$ real output, $Z$ the rental cost of capital. As R. Gordon and Veitch (1984) observe, this

formulation assumes that real wages are instantaneously inversely related to the rental cost of capital, so that any increase in real wages will be offset by lower capital costs, leaving the pure profitability of the firm unchanged.

"Thus the neoclassical approach leaves no room for theories that predict a profit squeeze, investment slump, and growth slowdown following a period of excessive real wage growth" (R. Gordon and Veitch, 1984, p. 11).

In models similar to that of Bruno and Sachs, Malinvaud $(1980,1982)$ suggests that the pure profit rate--the gap between 
the rate of return and the rental cost of capital--regulates investment spending in the mediun run. His investment equation (1980, p. 33) thus provides a channel whereby a profit squeeze induces an investment slump and prolonged unemployment (which, incidentally, often turns into the Keynesian variety). Malinvaud notes the similarity of his approach to the q-theory of . investment (Tobin and Brainard, 1977) but also acknowledgés that stock prices may be excessively speculative along the lines of Shiller (1981) for the q-ratio to provide much information about profitability. This suggestion is explored by Ueda and Yoshikawa $(1986)$.

A tradition associated with Kalecki (1971), Tinbergen (1938), Meyer and Kuh (1957) and Duesenberry (1958), emphasizes that firms employ a hierarchy of finance, with internal funds taking priority over borrowing or selling equity. A very clear description of the characteristics of the capital market which create financial constraints is Wood (1975, pp. 4-9).

The financial constraint hypothesis is questioned by neoclassical theorists on theoretical and econometric grounds. Eisner and Strotz (1963) comment on the theoretical foundation:

"One should not expect a firm, no matter how high its current profits or expected future profits, to wish to invest unless the contemplated addition to capital stock is expected to increase expected profits or have an expected return higher than that from alternative uses of funds." ( $p$. $124)$.

Jorgenson (1971) comments on the econometric evidence from the vantage point afforded by equation 8 above (he is largely responsible for its use): 
". . where internal finance variables appear as significant determinants of desired capital, they represent the level of output. When both output and cash flow are included as possible determinants, only one is a significant determinant" ( $p .1133$ ).

Econometric evidence in contradiction to Jorgenson's comment includes Fazzari and Mott (1986/87); Abel and Blanchard (1986) find that profitability plays a significant independent role in a q-theory investment equation.

In theoretical work, neo-Keynesian models (Asimakopolous 1971) frequently posit a direct relationship between expected profitability and the rate of capital accumulation. The equilibrium rate of profit and capital accumulation are then determined by the interaction of such an independent investment equation (some sort of independent investment function being the differentia specifica of Keynesian models) and the saving function which establishes what level of profitability will be realized for a given level of investment, through the Cambridge growth equation. 35

Hybrid investment models incorporating profitability are attracting more attention, perhaps as a reaction to the failure of any single investment model to dominate in econometric tests (Clark 1979; Kopke 1985). Taylor's (1985) theoretical model, for instance, combines elements of the q-theory and the accelerator. Gordon and Veitch (1984), Fazzari and Mott (1986/87), and Abel and Blanchard (1986) develop hybrid econometric models.

Facts which resist stylization. Table 10 presents some of the relevant aggregate data on capital formation and 
profitability in the nonfinancial corporate sector of the U.S. economy. These statistics illustrate the major theme raised by Bosworth: the 1970s is a period of normal capital accumulation. Only by comparison with the super-normal growth during 1960 s can a case be made for after-tax profitability slowing investment in the 1970s. This interpretation holds whether you judge investment by the share of net investment in net domestic product, or the ratio of real net investment to the real net stock of fixed capital.

These statistics resemble evidence for the total economy presented by Bosworth (1982, p. 275), providing an opportunity to return to the capital deepening explanation of the before-tax profitability decline. ${ }^{36}$ A problem is identified by Solow:

"Bosworth proposes to interpret the conjunction of rising capital-output ratio and falling rate of return as a more or less classical deepening of capital. The puzzle resides in the fact that the capital-labor ratio was almost flat in the second half of the the 1970 s and probably did not rise much between 1967 and 1980. If there is any technological progress at all, a constant capital-labor ratio would imply a falling capital-output ratio, so $I$ take it that even a small rise in the capital-labor ratio would be hard to reconcile with the perceptible rise in the capital-output ratio" (Solow, in Bosworth 1982, p. 320 ).

The rise in the capital-output ratio is clearly discernible in the fifth row of Table 10 and its correspondence with a period in which the capital-labor ratio was flat aligns with Solow's observation. In fact, the nonfinancial corporate capital-labor ratio grew about 1.06 per cent per annum over the 1971-1980 period, while the capital-output ratio grew by about 2.0 per cent per annum (about 17 per cent in total) over the same period. 
An interesting point is that the shares of net investment and after-tax operating surplus in net domestic product (rows 2 and 6) align closely from 1948 to 1980. Both bulge in the $1960 \mathrm{~s}$ (the arbitrary breakpoint at 1965 does a poor job of capturing the rise in investment which began only after 1963). Both settle down in the 1970 s to levels fairly close to their 1950 s averages. I return to this point below.

Declining capital productivity. The association between a rising capital-output ratio and a period of declining profitability points to Marx's Gesetz des tendenziellen Falls der Profitrate. Stated in the language of modern macroeconomics, Marx's Law might be described as an historical tendency for capital accumulation to generate capital-using technological innovation, which drives up the capital-output ratio and, unless neutralized by what Marx calls a "countervailing tendency", drives down the rate of profit.

Marx maintains that individual firms expand by investing in techniques which give them a cost advantage over their rivals and raise their private rate of return. As these techniques fan out through the the economy, they bring down the social rate of return as an unintended consequence of their use. The rate of profit declines because of firm myopia. 37 Why don't firms see the error of their ways and avoid such behavior? One might speculate that competition places firms in a kind of Prisoner's Dilemma writ large. Even if all the firms in an industry know that investment in the latest technology will reduce the industry 
rate of return if it becomes generalized, the payoff from having a monopoly on that technology and the potential loss from being beaten to the punch by rivals encourages "defection" rather than "cooperation".

Marx's prediction has generated intense criticism, most of it from Marxian economists themselves. 38 His own account provides the raw material for its critique, for Marx listed a series of potential "countervailing tendencies" which would suppress the decline in profitability. Critics argue that under normal circumstances, the countertendencies prevail. Okishio (1961) proves that if (1) real wages are constant and (2) firms adopt new techniques which lower unit costs at existing prices in a circulating capital model, then the new equilibrium profit rate established after new techniques are fully propagated will exceed the old rate. Despite a myopic decision rule, the rate of return exhibits a rising tendency unless inhibited by other factors, such as a wage-push profit squeeze.

It is now recognized that the Okishio Theorem can be turned around to support the original unintended consequences argument under several conditions. If it is assumed that real wages rise at the same rate as productivity (constant wage share), then firms which follow the decision rule (2) above will wind up lowering the social rate of return; Foley (1986A, pp. 45-47) provides a simple illustration. Further, in models with fixed capital (Shaikh 1978) or joint production (Salvadori 1981), the possibility of decision rules which lead to a decline in 
profitability has been demonstrated.

The distributional conditions for the Okishio Theorem (constant real wage) or the Anti-Okishio Theorem (real wage growth equal productivity growth) are extremes, and actual economies fall somewhere in between. 39 "Thus," writes Foley (1986A, p. 47), "the real economies fall into the class of cases where the movement of the rate of profit cannot be predicted on $\underline{a}$ priori theoretical grounds."

It will be useful to examine some empirical evidence bearing on the Marxian hypothesis. Figure 3 shows the ratio of net fixed capital stock to net domestic product of nonfinancial corporate sector, and the same ratio multiplied by the Federal Reserve Board's capacity utilization rate for manufacturing as a (rough) way of measuring the ratio of capital to potential output. The point is that both series hint at a rising trend. 40 The capitaloutput ratio declined in the 1960s, but after about 1966 it has been rising. It seems likely that extending the Weisskopf study (see previous section) to the 1980 s would generate results more in alignment with those of Bayer and Funke in Table 6 .

Table 11 reproduces the data on the manufacturing sectors of eleven countries from Chan-Lee and Sutch (1985A). The first column shows the full-period growth rate in the nominal outputcapital ratio. 41 From here out, I switch terminology and refer to the output-capital ratio (capital productivity) rather than its reciprocal. The full sample trend in capital productivity is downward by this index in every country except Italy, Belgium, 
and Norway.

Columns two and three break the changes in real capital productivity into two sub-periods, roughly the $1960 \mathrm{~s}$ and $1970 \mathrm{~s}$. The pattern observed in the nonfinancial corporate sector of the U.S. is mirrored in the behavior of the manufacturing aggregates in row one for the U.S., and significantly, this pattern is quite general. In every case, save Germany and Italy, capital. productivity growth slowed in the 1970s. Chan-Lee and Sutch observe that the profit decline in the late 1960s to early $1970 \mathrm{~s}$ was more tightly associated with distributional factors than in the later 1970s, when "the primary factor.. . appears to be capital productivity" (1985A, p. 76).

The evidence reviewed here is merely suggestive of the overmechanization or overaccumulation effects under consideration and alternative explanations can easily be fashioned. For example, the data in Table 11 are not cyclically adjusted, and declining capital productivity could merely reflect lower capacity utilization. Alternatively, a decline in the ratio of value added to capital could reflect the effect of raw material price increases in reducing the income of importing countries or sectors. It is also interesting that declining profitability precedes declining capital productivity (at least in the U.S.), in apparent violation of the Marxian theory.

The Marxian argument for a falling tendency in the profit rate raises the question of the consequences of declining profitability. Marx himself believed he had uncovered a tendency 
toward general economic crisis--sharp periods of reduced economic activity. A gradual decline in the rate of profit, however, need not imply such dranatic discontinuities in economic growth. "If the rate of profit were indeed falling consistently," writes Foley (1986B, p. 153), "why would the capitalist system not adapt to this fall through a gradual reduction in the rate of accumulation?"

Marx himself probably reasoned that a decline in profitability would ultimately result in a stagnation of the mass of profits, leading to a sharp reduction in capital outlays, and an oral tradition of explaining recent macroeconomic history in this way exists. On a ratio scale to ease growth comparisons, Figure 4 shows real fixed net investment and the deflated aftertax operating surplus of nonfinancial corporations. The impression that the 1970 s was a period of normalcy is called into question by these data. In real terms, net investment went flat after 1966. From 1966 to the peak in 1979 it grew at an annual rate of 1.2 per cent, compared to 4.1 per cent from 1948 to 1966. The mass of real profits stagnated in the same way, growing at an annual rate of 4.9 per cent from 1948 to 1966 and only 1.4 per cent from 1966 to the peak in 1978. From this perspective, the stagnation of the last two decades follows from the limits imposed on capital accumulation by the availability of profits. Taxes and profitability. The final issue I discuss is corporate taxation. The neo-keynesian theory of distribution developed by Kalecki, Kaldor, Robinson, Pasinetti and others 
posits a causal role for investment demand in shaping the functional distribution of income. This theory is conveniently addressed in a discussion of tax incidence.

Three complicating factors in the taxation of corporate income are the tax treatment of interest, inflation, and the tax codes. Because interest is exempt from the corporate income tax, increases in the interest share of operating surplus will-lower the effective tax rate on capital income. It is customary to assume that firms finance themselves with an optimal mix of debt and equity that maximizes the benefits of the tax shield in the interests of shareholders. The secular increase in debtfinancing has contributed to a decline in effective tax rates. ${ }^{42}$ Inflation increases effective tax rates (see the discussion of IVA in the first section). Effective statutory rates have been repeatedly reduced over the last three decades, mainly through the vehicle of liberalized depreciation or investment tax credits.

In combination these three factors created a downward trend in the effective tax rate on net operating surplus until around 1967, and a plateau through the 1970s. Figure 5 shows the effective tax rate on operating surplus and on corporate economic profits. The tax rates on total capital income estimated by Feldstein et. al. (1983) include state and local corporate taxes, as well as the taxes on dividends, capital gains and interest paid by the shareholders and creditors of nonfinancial corporations. This more comprehensive rate actually rose in the 
$1970 \mathrm{~s}$ to $1950 \mathrm{~s}$ levels.

The economic incidence of corporate income taxes remains a vexing issue. Opinions vary from no shifting to full shifting; an informal oral poll convinces me that many probably settle for the golden mean -- fifty per cent shifting. Empirical evidence of short-run shifting runs from none (R. Gordon 1967) to full (Krzyzanick and Musgrave 1964).

In short-run models of partial equilibrium, it is hard to imagine how firms could shift any of the corporate income tax. If they are maximizing profit before the tax is imposed, they will continue to maximize after-tax profit at the same combination of price and output after the tax is imposed. By treating corporate taxes as direct taxes, the national income accounts align closely with the short-run model in which shareholders bear the entire burden of profit taxes.

Given that the nonfinancial corporate sector accounts for about two-thirds of privately produced output in the U.S., a partial equilibrium analysis is probably not appropriate, and several general equilibrium or macroeconomic models have been proposed to tackle the incidence problem. In neoclassical models following Harberger (1962) corporate capital avoids some of the tax by shifting to the noncorporate sector, but capital income (regardless of legal form) still bears some of the burden of taxation, how much depending on the parameters of the model.

A short-period theory of incidence in the Keynesian tradition arrives at the full shifting conclusion by virtue of 
its distinctive Keynesian treatment of investment. In Asimakopolous and Burbidge (1974), investment is assumed exogenous in real terms. By further assuming that all saving is out of mark-up income leither retained earnings or saving by rentiers), and (for comparison with the neoclassical result) that full employment is maintained, they show that an increase in the corporate profit tax which finances a balanced budget increase in government spending is entirely born by lower after-tax real wages.

The mechanism illustrates very nicely the logical structure of neo-Keynesian theory. Under the investment and saving assumptions mentioned, after-tax profits are equal to the sum of rentier consumption, investment, the trade surplus and the government deficit following Kalecki's (1971, pp. 78-93) profit identity; also see Keynes's famous "widow's cruse" discussion (1930, p. 139). Assume a closed economy to get rid of current account issues. Firms set prices in equilibrium by marking up unit costs; the mark-up must be consistent with the profit identity at the equilibrium levels of its variables. A corporate profit tax together with a rise in government spending creates an excess demand for saving. Under the assumption of full employment output, firms raise their mark-ups until enough saving is generated to eliminate the excess demand. The entire burden of the tax falls on workers, whose money wages are assumed to remain constant while the price level rises. In case of underemployment equilibrium, excess demand for saving can also be 
eliminated by an increase in output.

This model is similar to the long-run growth model of Kaldor (1956). Kaldor assumes the rate of investment is exogenously given at a level which continuously maintains the full employment of a growing labor force.43 A corporate profit tax will fall entirely on wages since the after-tax share of profits is determined by the exogenously determined level of investment and output, and the savings propensities out of wages and profits. 44

Kaldor recognizes the possibility that real wages are not sufficiently flexible to permit exogenous investment spending to determine the distribution of income, in which case, he observes, we are back in a Ricardo-Marx world. In this world, investment is limited by the available saving out of profits, and not the other way around. Taxes are borne by capital income because workers are capable of resisting reductions in their real wage. This modification of the Keynesian model represents a tradition that runs through Joan Robinson's "inflation barrier" straight to the Marx-Keynes synthetic models of Marglin and Taylor. In Marglin's hybrid model, for example, tax incidence ultimately is determined in a bargaining setting; see the discussion in Marglin $(1984 \mathrm{~B}$, pp. $138-40)$.

Neoclassical growth models focus on the balanced budget effects of corporate taxes on the accumulation of capital. By raising the rental cost of capital, a tax on capital reduces the equilibrium level of capital per efficiency unit of labor. Under diminishing returns, the before-tax rate of profit rises. 
Whether it rises enough to neutralize the effects of the tax depends. Atkinson and Stiglitz (1980, pp. 238-39) show that in the case of an extreme classical saving function (no saving out of wages), the after-tax rate of return remains constant, just as it might in Kaldor's model. In a more general case, in which the saving propensity out of profits exceeds that out of wages, the degree of shifting depends on the parameters of the model.45 The long-run neoclassical growth model suggests that a tax reduction stimulates greater capital intensity and lowers the before-tax rate of profit. Tax rates and the before-tax rate of return move in the same direction while tax rates and the aftertax rate of profit move in opposite directions. The Kaldoriantype model suggests the same pattern between taxes and the before-tax rate of profit, as firms increase their mark-ups whenever the tax rate is increased and vice versa.

Over the long haul, as effective tax rates have fallen, so has the before-tax rate of return, while the after-tax rate of return has exhibited no clear trend. Moreover, the timing has been awkward from the perspective of a simple application of the neoclassical model. As Feldstein et. al. (1983, p. 154) observe, there "appears to have been no tendency for pretax profits to vary in a way that offsets differences in effective tax rates." (The tax rate under consideration is that on total capital income, which would be indicated by neoclassical theory.) On the other hand, the neo-Keynesian theory of distribution essentially predicts that changes in the after-tax share of 
capital income should follow movements in the share of investment spending; with full shifting, what happens to before-tax profits is irrelevant. Table 10 shows that the after-tax net operating surplus and net fixed investment (as shares of nonfinancial corporate net domestic product) correspond loosely in their movements. The obvious exception, the 1980's, makes sense from the perspective of Kalecki's profit identity because budget deficits remained larger than the current account deficit until about 1986. A bulge in profitability in the 1960s aligns with a bulge of similar magnitude in net investment, although this correlation does little to establish causation, and it is significant that profitability increased before net investment.

In the Ricardo-Marx tradition, and in the Keynes-Marx hybrid models, profit tax shifting is less than complete; the before-tax rate of profit is not irrelevant. Could declines in the beforetax rate of profit have been cushioned by the political influence of business in the U.S. in convincing Congress (with appeals to the the national saving rate) to lower effective tax burdens? In one short-period model of Asimakopolous and Burbidge (1974, Table IIa, case i), shifting from corporate taxes to wage taxes to finance the same level of government spending reduces the level of aggregate demand for any given level of investment. It would be interesting to know what the properties of a similar move might be in a more dynamic setting (e.g. with an investment function), and particularly what the net effect on investment would be. 
Concluding thoughts. Rather than attempt a summary, I offer an observation. In the heyday of growth theory, Kaldor

challenged us to explain the "stylized facts" of long-run growth: rising ratios of capital and output to labor, constant ratios of output and profits to capital. The evidence under review here challenges us to explain some stylization-resistant facts of medium-run growth (and stagnation) involving the same ratios.

Decline at an uneven rate, rather than constancy, has characterized the before-tax rate of profit over the post-war period in the U.S. and other industrial countries. These declines have been associated with smaller profit shares and, in later years, often with lower output-capital ratios. The aftertax rate of return has shown no Iong-run trend in the U.S., and has declined less sharply than the before-tax rate in most other industrial countries. In the U.S., there is a noticeable bulge in both profit rates in the $1960 \mathrm{~s}$. From the variety of explanations of these patterns offered by representatives of different schools of thought, and from the divergent significance attached to these facts by alternative theories, it is clear that macroeconomic profitability offers a rich and important field for theoretical and practical investigation. 


\section{ENDNOTES}

1. For recent works which compare the logical structures of these three competing paradigms, consult Harris (1978) and Marglin (1984A). Recent contributions by neoclassical economists which elucidate the role of profitability are Malinvaud (1980, $1982)$ and Bruno and Sachs (1985). Contributions that synthesize elements of Marxian and Keynesian theory are Taylor (1985) and Marglin (1984A, 1984B). For somewhat more Keynesian views of the same issues, see Nell (1985) or Dutt (1984). Aspects of the Marxian theory of economic growth appear in growth cycle models in the tradition of Kalecki (1971) or Goodwin (1967). Foley $(1987)$ is a recent development.

2. For additional discussion of accrued versus realized holding gains, and alternative income concepts, see Shoven and Bulow $(1975,1976)$. For discussion of the state of the art among practicing accountants, see Financial Accounting Standards Board (1984, Statement \#33).

3. Financial accounts treat future expenditures associated with plant closures, company reorganizations, and the like as current expenses, while the NIPAs recognize them as expenses only when made. This difference can lead to discrepancies between reported and NIPA profits; see U.S. Department of Commerce, Bureau of Economic Analysis (1985A, Appendix A). I am indebted to Kenneth Petrick of the Bureau of Economic Analysis for calling this to my attention.

4. King and Fullerton (1984, pp. 204-214) provide a summary of changes in the tax codes. Other chapters describe the prevalence of such liberalization of depreciation schedules in other industrial countries.

5. For the methodology used in calculating the IVA, see U.S. Department of Commerce, Bureau of Economic Analysis (1976, pp. 135-38) or see Ruggles and Ruggles (1956, pp. 180-181).

6. Shoven and Bulow use constant dollar accounting to capture gains on fixed capital and constant dollar FIFO for inventory gains. They also include accrued holding gains from changes in the market value of net financial liabilities, which I have ignored.

7. I ignore imputed interest payments out of sympathy for the Ricardo-Marx tradition. Imputing interest suppresses the redistribution of surplus value from productive enterprises, where it originates, to financial enterprises. Pollin (1986) treats imputed interest in the same way as $I$ but also deducts the inflation premium from net interest on the grounds that it is really a repayment of principal. 
8. For some discussion of the methodology of estimating capital stocks and the evidence about actual patterns of their decay, consult U.S. Department of Labor, Bureau of Labor Statistics (1983, Appendix C) or Young and Musgrave (1980, pp. 32-36).

9. The reader may wish to consult the June 1984 American Economic Review for the lively controversy Fisher and McGowen stimulated.

10. Replacing the assumption of balanced sets of projects with one of constant exponential growth improves the accuracy of accounting rates under some conditions. If the growth rate equals the internal rate, both gross and net accounting rates will too. For an accountant, living is easy on a Von Neumann growth path.

11. The simplest way to adjust for the cycle is to calculate the rate of profit on capital stock actually in use. The growth accounting framework developed by Weisskopf and discussed below effectively proceeds in this way.

12. Studies not included in Table 3 are Corcoran (1977), Runyon (1979), Schultze (1975), and Okun and Perry (1970). Scanlon (1981) provides an overview of the $1970 \mathrm{~s}$ literature.

13. For an introduction, consult Coutts et al. (1978), Nordhaus and Godley (1972), and Sylos-Labini (1979A).

14. Okun (1981) provides an influential rationalization for price stickiness: customer markets. It is now clear that price rigidity (non-clearing markets) is perhaps the major divide between New Classical economists and the mainstream. NeoKeynesians seem split over how much autonomy firms have in their pricing policy.

15. See Fay and Medoff (1985) for an introduction to the paradox of short run increasing returns to labor. It is paradoxical because it contradicts a simple diminishing returns theory of the firm.

16. This equation applies to the short run, so capital stock is fixed. With a constant mark-up, the real wage $(w / p)$ is also fixed in this simple model. Thus,

$$
b_{1}=\frac{w(1+m) L_{n}-a_{1}}{p K}
$$

17. Like all conveniences, this one breaks down. Feldstein and Summers (1977) express some concern about the large value of their trend term without the cyclical controls, even though it is nonsignificant. 
18. Runyon (1979) similarly argues that the bulge of the 1960s is more puzzling than the slump of the 1970s. An extraordinary feature of the $1960 \mathrm{~s}$ was the exceptionally high level of investment, which serves to realize profits through a well-known Kaleckian mechanism. I return to this theme below.

19. In Weisskopf, the latter two are called the realization failure and rising organic composition of capital hypotheses, following established Marxian categories.

20. Feldstein et al. (1983) experiment with richer cyclical controls to capture the asymmetry.

21. Munley (1981) takes exception to the idea that the declining profit share in phase $B$ results from worker strength, observing that real wages actually grow more rapidly (by a factor of from 1.2 to 2.8) during phase A. See also Weisskopf's (1981) rejoinder. Another hypothesis that might explain the phase $B$ profit squeeze is that raw material prices shoot up in this period, as suggested by Kalecki (1971, pp. 62-64). This hypothesis could be studied using the mark-up pricing method described in the text.

22. In neoclassical theory, the rental cost of capital reduces to three components: the relative price of one unit of capital, the tax liability of using it, and the after-tax opportunity cost of funding it. I adopt the convention of calling the latter component the cost of funds.

23. Both arguments predict a decline in the rate of profit but obviously can only explain a drop in the share of profit on condition that the elasticity of substitution is less than unity. See Nordhaus (1974, pp. 195-196).

24. Taxes, inflation, oligopoly, and intangible assets can drive $q$ away from unity, and there is also the problem that q-theory indicates the use of marginal q while researchers utilize average q. See Summers (1981) or Von Furstenberg (1977). Abel and Blanchard (1986) is a rare use of marginal q.

25. For additional comparisons of q-ratios, see Brainard et al. (1980), also a good entry point to the literature on why markets seem to have undervalued firms in the 1970s. Also recommended: Modigliani and Cohn (1979) and Kopke (1982).

26. This same line of reasoning applies to a closed economy. Shepherd (1982) maintains that the share of U.S. national income produced under effectively competitive conditions has increased from 56 to 77 percent from 1958 to 1980 . Import penetration is one of three explanatory factors. 
27. This seminal work in the neo-Marxian profit squeeze tradition was followed by a more cyclical version, Boddy and Crotty (1975).

28. One difference is that Bowles et al. (1986, p. 155) deny that profitability rose substantially in the $1980 \mathrm{~s}$, while Clark finds an increase in the cyclically adjusted profit share in this period.

29. Let A represent the technology matrix of a circulating capital economy, 1 the vector of direct labor requirements, w the money wage, and $r$ the equilibrium rate of profit. The equilibrium price vector, p, satisfies

$$
\mathrm{p}=(1+\mathrm{r}) \mathrm{pA}+\mathrm{w} l
$$

and $r$ is the reciprocal of the dominant eigenvalue of the matrix $(I-A)^{-1}$. Wolff incorporates fixed capital, but the procedure is basically the same.

30. This interpretation of the movement along row 1 as a pure effect of technical change is my own. In a footnote, Wolff ( $p$. $108, n$. 25) observes that if the composition of real consumption changes while its level remains constant, the rate of profit rises along row 1 .

31. The existence of a strictly convex factor price frontier was the object of the Cambridge capital controversy; see Harcourt (1972). It appears that rumors of the death of the aggregate production function were exaggerated. Neoclassical economists continue to use it, fully aware of serious methodological problems, probably because it provides a tractable analytic framework and a good econometric fit.

32. Malinvaud (1977) assumes "putty-clay" technology, but with different vintages of clay extant, product wages will be too high to use the least efficient machines, and classical unemployment breaks out.

33. To be precise, they estimate:

$$
r=a_{0}+a_{1 x t}-a_{1 w}-a_{2} p_{n}+a_{3 j}
$$

with $r, w, p_{n}$, and $j$ the rate of profit, product wage in gross output units, relative price of raw materials, and capacity utilization (all in logarithms), $x$ is the rate of Harrod neutral technological progress, and $t$ is time. 
34. In the second OPEC shock, they argue that the saving function shifted down by more than the investment function, driving interest rates up. Note that temporary price shocks will not reduce investment today since firms equate the marginal product of future capital stocks with the rental of capital.

35. The Cambridge growth equation is $g=s p r$ where $g$ is the rate of capital accumulation and $s p$ is the saving rate out of profits. See Pasinetti (1974, Chs. 5-6), Marglin (1984A), or Robinson (1964, pp. 48-49).

36. Besides the low cost of funds hypothesis, another explanation based on capital deepening is that of slower neutral technical progress. With slower Harrod-neutral technical progress, capital becomes more abundant relative to labor measured in efficiency units. Feldstein et al. (1983, p. 151) add productivity growth to their profit rate equation on these grounds, I believe.

37. Leontief (1985) has a myopic firm hypothesis that is a photographic negative of Marx's. To wit, firms do not recognize that a new technology when fully propagated will increase the social rate of return because they can only assess its affects on their profitability. The parallels between Marx and Schumpeter (sans the falling profit tendency) on profits and technical dynamism should also be noted.

38. See Van Parijs (1980) and references therein.

39. Unlike neoclassical economists, Marxian economists retain the classical distinction between productive and unproductive labor, and define productivity over the former. Thus, a constant wage share (including unproductive workers) is consistent with productivity growth in excess of real wage growth. The rate of surplus value then rises; see Moseley (1985).

40. I regressed the raw and adjusted capital-output ratios on time. The coefficients and t-statistics are: 0.005 (2.77) and $0.002(1.40)$.

41. Since GOS/KG = (GOS/VA) $(\mathrm{VA} / \mathrm{KG})$, the growth rate of $\mathrm{VA} / \mathrm{KG}$ equals the growth rate of GOS/KG minus that of GOS/VA.

42. I plead guilty to inattention to the link between profitability and finance, particularly the implications of rising corporate indebtedness. The work of Minsky (see Minsky 1986 and references therein) has been influential in this regard. Also see Pollin (1986). 
43. Neo-Keynesian theory relies critically on "investor sovereignty", viz. that investment is exogenous (in some sense) because firms have superior access to finance (see Marglin 1984A, p. 322). This view comes under attack in Asimakopolous (1983).

44. Indeed, Kaldor concludes that "the incidence of all taxes. - falls on wages"(1956, p. 96). Recent work by Marrelli and Salvadori (1983) with a more general saving function shows that full shifting is probably a special case.

45. This marriage of Keynesian and neoclassical elements. is de rigeur in growth theory and its applications. Atkinson and Stiglitz assume a well-behaved neoclassical production function. Marrelli and Salvadori (1983) allow for a nore general technological relationship between the rate of profit and capital output ratio. 
Table 1. Comparisons of Revised and Old NIPA Series on Corporate Profits, U.S., Selected Years.

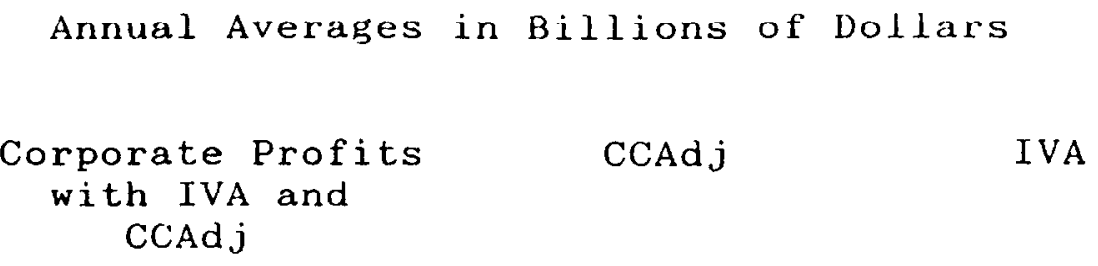

$\begin{array}{lrrrrrr}\text { Years } & \text { New } & \text { Old } & \text { New } & \text { Old } & \text { New } & \text { Old } \\ 1953-60 & 44.2 & 42.2 & -1.2 & -2.9 & -1.0 & -1.0 \\ 1961-70 & 74.7 & 72.9 & 4.4 & 2.9 & 2.1 & 2.1 \\ 1971-80 & 141.4 & 136.1 & -4.8 & -7.3 & -22.4 & -22.4 \\ 1981-84 & 204.1 & 214.9 & 6.9 & 21.1 & -12.7 & -12.5\end{array}$

SOURCES: Old series: U.S. Department of Commerce, Bureau of Economic Analysis (1985B, Appendix II). New series: U.S. Department of Commerce, Bureau of Economic Analysis (1986A, Table 1.14) and updates. 
Table 2. Comparisons of Revised and Old Series on Net Capital Stock in Current Dollars, U.S., Selected Years.

\begin{tabular}{lrrrrr} 
& Ratio of Revised Series to old Series \\
& \multicolumn{7}{c}{ Years } \\
Sector & 1948 & 1969 & 1973 & 1977 & 1981 \\
Corporate & 1.03 & 1.06 & 1.06 & 1.07 & 1.08 \\
$\quad$ Nonfinancial & 1.02 & 1.05 & 1.07 & 1.08 & 1.08 \\
Manufacturing & .89 & .95 & 1.03 & 1.05 & 1.04
\end{tabular}

SOURCE: Gorman et al. (1985). 
Table 3. Studies of Macroeconomic Profitability in the U.S.

\begin{tabular}{|c|c|c|c|c|c|c|}
\hline Author & Years & Coverage & Concept & Cycle control & Trend & Finding \\
\hline Nordhaus (1974) & $1943-73$ & NFC & BT NOS & Mark-up pricing & na & $\begin{array}{l}\text { Predicted NDS exceeds actual } \\
\text { from } 1909 \text { to } 1973\end{array}$ \\
\hline $\begin{array}{l}\text { Feldstein and Summersa } \\
(1977)\end{array}$ & $19 \div 9-76$ & NFC & $\mathrm{KN}+\mathrm{BT} \underset{\mathrm{NOS}}{\mathrm{NV}}+\mathrm{L}$ & $\begin{array}{l}\text { FRB CU } \\
\text { (of Wharton CU } \\
\text { or GXP Gap) }\end{array}$ & $\begin{array}{l}\text { Simple trend } \\
\text { Trend/shift } \\
\text { l970s dumg }\end{array}$ & $\begin{array}{l}\text { Nonsignificant negative trend } \\
\text { Nonsignificant negative trend } \\
\text { Vonsignificant negative shift }\end{array}$ \\
\hline & & & $\begin{array}{l}\text { BT GOS } \\
K G+I N V+L\end{array}$ & & $\begin{array}{l}\text { Simple trend } \\
\text { Trend/shift } \\
1970 \text { dumg }\end{array}$ & $\begin{array}{l}\text { Nonsignificant negative trend } \\
\text { Nonsignificant positive trend } \\
\text { Significant negative shift }\end{array}$ \\
\hline Lovel1 (1978)a & $\begin{array}{l}1949 \text { I- } \\
197 \text { III }\end{array}$ & $\mathrm{NFC}$ & $\begin{array}{l}\text { BT NOS } \\
\text { KN } \\
\text { AT NOS } \\
\text { RH }\end{array}$ & GNP GaD & $\begin{array}{l}\text { Trends w! bends } \\
\text { at } 65,70\end{array}$ & $\begin{array}{l}\text { Negative, negative, positive } \\
\text { trend segments } \\
\text { Positive, negative, positive } \\
\text { trend segments }\end{array}$ \\
\hline Kopke $(19 ; 8)$ & $\begin{array}{l}1953 \mathrm{I}- \\
1976 \mathrm{IV}\end{array}$ & NFC & $\begin{array}{l}\text { AT NOS } \\
X N+I N Y+L\end{array}$ & $\begin{array}{l}\text { BEA and FRS } \mathrm{CU} \\
\text { GSP GaP } \\
\text { Enemplogment rate }\end{array}$ & $\begin{array}{l}\text { Trends w/ bends } \\
\text { at } 05\end{array}$ & $\begin{array}{l}\text { Positive, negative } \\
\text { seguents }\end{array}$ \\
\hline Liebling (1980)a & $1950-77$ & NFC & $\begin{array}{l}\text { BT NOS } \\
\text { KN + INV } \\
\text { AT NOS } \\
\text { RN + INV }\end{array}$ & $\begin{array}{l}\text { Fra CU } \\
\text { (or others) }\end{array}$ & $\begin{array}{l}\text { Trend/shift } \\
62-68 \text { dummy }\end{array}$ & $\begin{array}{l}\text { Significant negative trend } \\
\text { Significant positive shift } \\
\text { Nonsignificant positive treno } \\
\text { Significant positive shift }\end{array}$ \\
\hline Grimm $(1982)^{a}$ & $1950-79$ & $\mathrm{NFC}$ & $\begin{array}{l}\text { BT } \underset{K N}{\mathrm{NOS}} \\
\mathrm{AT} \operatorname{RN}_{\mathrm{KN}}^{\mathrm{NOS}}\end{array}$ & $\begin{array}{l}\text { FRB CU } \\
\text { Epoductiptty } \\
\text { inflation rate }\end{array}$ & $\begin{array}{l}\text { Trend/shift } \\
1970 \text { s duamy }\end{array}$ & $\begin{array}{l}\text { Significant positive trend } \\
\text { Significant negative shift } \\
\\
\text { Significant positive trend } \\
\text { Significant negative snift }\end{array}$ \\
\hline Bosworth $(1982)^{b}$ & $1950-80$ & $\begin{array}{l}\text { Nonfarm } \\
\text { Business } \\
\text { NFC }\end{array}$ & $\begin{array}{l}\text { BT HOS } \\
K G+I N V+L\end{array}$ & $\begin{aligned} & \text { GuP Gap } \\
& \therefore \text { Yeal GXY }\end{aligned}$ & None & $\begin{array}{l}\text { Cyclical1y adjusted series } \\
\text { declines, } 67-90 \\
\text { Cyclical1y adjusted series } \\
\text { declines, } 67-80\end{array}$ \\
\hline
\end{tabular}


Feldstein et alc
$(1953)$

$\stackrel{N}{N}$
$\operatorname{A1man}(1953)$

1952-81 Business

NFC

Holland and Myersa

(1984)
BT NOS

$\mathrm{Kn}$

\section{BT NOS}

$\mathrm{KN}+\mathrm{INV}$

BT NOS

$\mathrm{KN}+\mathrm{INV}+\mathrm{L}+\mathrm{H}$

AT NOS

$\mathrm{KN}+\mathrm{INV}$

AT NOS

$\mathrm{KN}+\mathrm{INN}+\mathrm{L}+\mathrm{N}$

\begin{abstract}
BT NOS
$\mathrm{NN}+\mathrm{INV}+\mathrm{I}$
\end{abstract}

AT NOS

$\mathrm{BN}+\mathrm{IPV}+\mathrm{I}$

C1a=l: $(.984)$

$1954 \mathrm{I}-$

NFC

$1983 I V$
FRB CU

FRB $C U$

Vumal ro: recovery after trough

Index of quarters vefore peak

GNP Gap

\% Real GNP inflation rate

Trond/shift 1970 s dum

Trend w bend a 73 and shift 1970 dumat

Simple trend

Trends wends at 65 and 71

:onsignificant positive $=r e n d$ Significant negative shift

Siousignificant onsitive trend Significant negative shizt

Positive, positive segreri:s Signiticant negative shifi

Siznificant negative trend Signficant negative trend

Consignizicant negazive trend Significant negative sift

Vonsignificant negetive trend sinnificant negatire shift

Sonsignificant posizive trend Consizaizicant nogative shift

Significant positive trend honsignificant uegiative shif

Significan: nositive, negative, nonsizaizicant neative seguer:s

Eizn:Ejcant posit: :e negative, nonsignificant positime segrents

Decline in acjusted share, $65-70 ;$ Rise From $6 i-83$

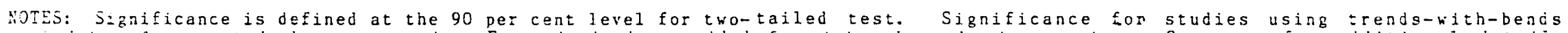

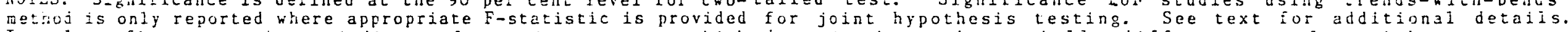

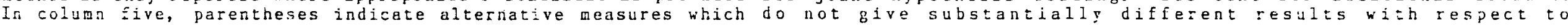
significance of trends or sifits.

a Studies reporting a battery of results.

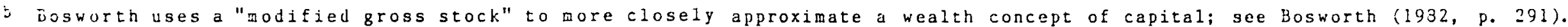

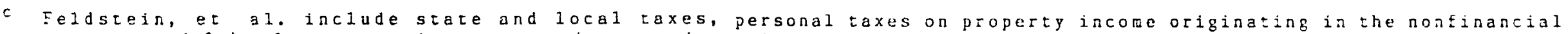
corporate sector, and federal corporate income taxes in measuring before-tax proftt.

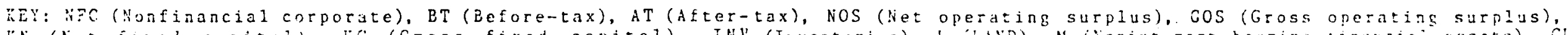

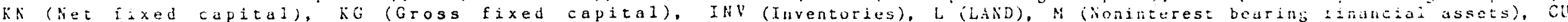
(capacief urilization index), FRe (Federal Reserve Board), BEA (Bureau of Economic Analysis). 
Table 4. Rates of Profita in Manufacturing, Nine Countries, Selected Years.

Per Cent

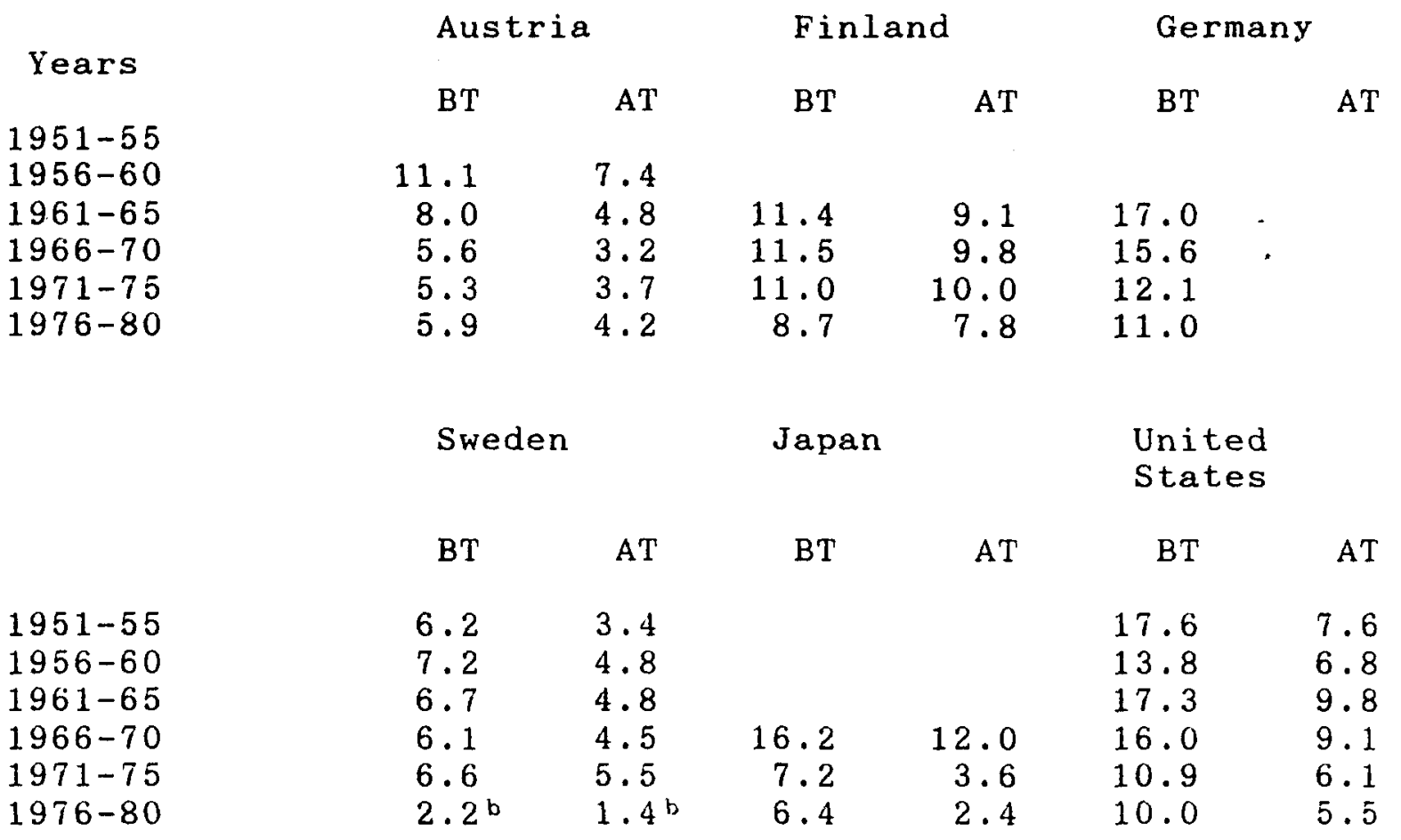

France

BT

AT

AT

Canada

$1951-55$

$1956-60$

$1961-65$

$1966-70$

$1971-75$

$1976-80$

$\begin{array}{rrrlll}8.7 & 5.5 & & & 15.4 & 8.2 \\ 7.9 & 5.8 & 9.9 & 7.4 & 11.4 & 6.6 \\ 5.8 & 4.7 & 10.7 & 8.4 & 12.0 & 6.1 \\ 2.4 & 2.7 & 10.0 & 7.4 & 11.2 & 6.7 \\ & & 6.4^{\mathrm{c}} & 4.3^{\mathrm{c}} & 9.1^{\mathrm{d}} & 5.3^{\mathrm{d}}\end{array}$

SOURCE: Holland (1984, Table 1-1).

NOTES: a Before-tax (BT) and after-tax (AT) net operating surplus divided by plant, equipment, and inventories.
b $\quad 1976-78$
C $\quad 1976-79$
d $\quad 1976$ 
Table 5. Studies of Macroeconomic Profitability, Selected Countries

\begin{tabular}{|c|c|c|c|c|c|c|}
\hline Author & Years & Sector & Concept & Cycle Control & Trend & Find:ns \\
\hline \multirow[t]{2}{*}{ Ho:land and Myersa } & $1947-81$ & $\begin{array}{l}\text { U.S. } \\
\text { Mfg }\end{array}$ & $\begin{array}{l}B T \text { NOS } \\
\text { KN }+ \text { INV }\end{array}$ & $\begin{array}{l}\% \text { Real GNP } \\
\text { Inflation }\end{array}$ & $\begin{array}{l}\text { Trend'si: }= \pm \\
70-31 \text { du=1 }\end{array}$ & $\begin{array}{l}\text { Vonsignificant negative erend } \\
\text { Significant negative shist }\end{array}$ \\
\hline & & & $\begin{array}{l}A T N O S \\
K N+I N V\end{array}$ & & & $\begin{array}{l}\text { Nonsizrificant positive taend } \\
\text { Nonsignificant maginaigl } \\
\text { negative stift }\end{array}$ \\
\hline hilitians & $1961-77$ & $\begin{array}{l}U \cdot \bar{R} \text {. } \\
M f_{E} \text {. }\end{array}$ & $\begin{array}{l}B T N O S \\
K N+I N V\end{array}$ & ${ }_{C U}^{\circ}$ Costs & Simpie $=: \in$ nd & Signizicant nezative trenc \\
\hline \multirow[t]{2}{*}{ Sertmar } & $1951-78$ & $\begin{array}{l}\text { Sweden } \\
\text { Corporate }\end{array}$ & $\begin{array}{l}\text { BT NOS } \\
\text { RN }\end{array}$ & $\begin{array}{l}\% \text { Real GNP } \\
\text { Inflation }\end{array}$ & Siaple =and & Significan: negative trend \\
\hline & & & $\operatorname{AT} \operatorname{RN}^{N O S}$ & & & Ionsianizicant posirive =rend \\
\hline \multirow[t]{4}{*}{ King and Mairresse } & $1956-73$ & $\begin{array}{l}U . K \\
M f_{g}\end{array}$ & $\begin{array}{l}\text { BT NOS } \\
\text { KN }+ \text { INV }\end{array}$ & $\begin{array}{l}C U \\
C U(t+1)\end{array}$ & Irend stats & $\begin{array}{l}\text { Sinnifizant negalive trend } \\
\text { Stenizizant negative shits }\end{array}$ \\
\hline & & & $\begin{array}{c}\text { AT NOS } \\
\qquad N+I N V\end{array}$ & & & 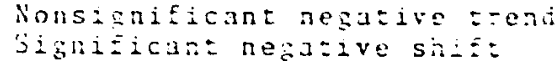 \\
\hline & & $\begin{array}{l}\text { France } \\
\text { Mf }\end{array}$ & $\begin{array}{l}\text { BT NOS } \\
\text { KN + INY }\end{array}$ & & & 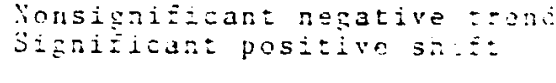 \\
\hline & & & $\begin{array}{l}\text { AT NOS } \\
\text { EN }+ \text { INY }\end{array}$ & & & $\begin{array}{l}\text { Significant positive tzend } \\
\text { donsigaizicant positive stitet }\end{array}$ \\
\hline \multirow[t]{2}{*}{ Sayer } & $1956-80$ & $\begin{array}{l}\text { Austria } \\
\text { Mining } \\
\text { Mfg }\end{array}$ & $\begin{array}{l}\text { BT NOS } \\
R N+I N V+M\end{array}$ & $\%$ : Real Gi: & Siagle taend & Signizican: negative trenc \\
\hline & & & $\begin{array}{l}\text { AT NOS } \\
K N+I N V+M\end{array}$ & & $\cdot \cdot$ & Significant negazive =renc \\
\hline Roskenkylo & $1961-80$ & $\begin{array}{l}\text { Fin1 and } \\
\text { Mfg }\end{array}$ & $\begin{array}{l}\text { BT NOS } \\
K N+I N V\end{array}$ & $\begin{array}{l}\% \text { Mfg output } \\
\text { Intlation }\end{array}$ & Single trend & Signizicant negazive trend \\
\hline & & & AT NOS & & & Aonsiznificant neqative trend \\
\hline
\end{tabular}


Tarasofsky
$\therefore$ isach
!76́-31 German

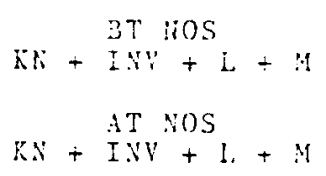

BT NOS
$\mathrm{N}+$ INH

AT NOS

$B H+I N V+L$

Mf 8

BT nos

At NOS

$5 x+I N Y+1$
Uneaploynent rate - high eariogment unempoyent rase

inpie trens

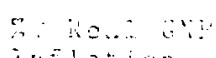

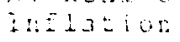

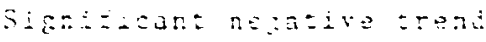

Siznizicart nesz:ive Erend

SOLRCE: AII studies are in llolland ( 1984 ).

NOIES: See notes to Table 3 and text for details.

a For tioliand and Myers results on MFC sector, see Table 3. 
Table 6. Decomposition of Secular Changes in the Rate of Profit: Three studies.

$$
\begin{gathered}
\text { Growth Rates of Variables } \\
\text { Per Cent Per Annum }
\end{gathered}
$$

\begin{tabular}{|c|c|c|c|}
\hline Variable & $\begin{array}{c}\text { Weisskopf } \\
\text { U.S. NFC } \\
1949 . \mathrm{I}-1975 . I\end{array}$ & $\begin{array}{c}\text { Bayer } \\
\text { Austrian Mfg. } \\
1958-1977\end{array}$ & $\begin{array}{c}\text { Funke } \\
\text { U.K. Mfg. } \\
1951-1979\end{array}$ \\
\hline $\mathbf{r}$ & -1.2 & $-5 \cdot 3$ & -4.02 \\
\hline (NOS/VA) & -1.24 & -3.5 & -2.37 \\
\hline$\left(\mathrm{VA} / \mathrm{VA}_{\mathrm{f}}\right)$ & +0.02 & -0.1 & -0.18 \\
\hline$\left(\mathrm{VA}_{\mathrm{f}} / \mathrm{pK}\right)$ & +0.02 & -1.7 & -1.47 \\
\hline
\end{tabular}

SOURCES: Weisskopf (1979, Table 3), Bayer (1984, Table 11-8), Funke (1986, Table 3$)$.

NOTES: Bayer's data appear to contain an error and have been recalculated. Funke's data are my calculations of simple averages of six cycles from Table 3 . See text for description of variables. 
Table 7. Decomposition of Average Changes in the Rate of Profit During the B Phase of Cycle: Three Studies.

$$
\begin{gathered}
\text { Growth Rates of Variables } \\
\text { Per Cent Per Annum }
\end{gathered}
$$

$\begin{array}{cccc} & \text { Weisskopf } & \text { Bayer } & \text { Funke } \\ \text { Variable } & \text { U.S.NFC } & \begin{array}{c}\text { Austrian Mfg. } \\ 1958-1977\end{array} & \text { U.K. Mfg. } \\ 1949 . \mathrm{I}-1975 . \mathrm{I} & & & -1951-1979 \\ \mathrm{r} & -10.1 & -7.6 & -6.4 \\ (\mathrm{NOS} / \mathrm{VA}) & -8.8 & -6.1 & -5.6 \\ (\mathrm{VA} / \mathrm{VAf}) & +0.5 & +0.5 & +2.3 \\ (\mathrm{VAf} / \mathrm{pK}) & -1.8 & -2.3 & -3.1\end{array}$

SOURCES: Weisskopf (1979, Table 4), Bayer (1984, Table 11-8), Funke (1986, Table A3).

NOTES: Bayer's data do not add up due to rounding error. Funke's data are my calculations of averages for six cycles from Table A3. See text for explanation of variables. 
Table 8. Tobin's $q$, the cost of Funds, and the Rate of Profit For Nonfinancial Corporations, U.S., Selected Periods.

Average Values

$\begin{array}{lccc}\text { Years } & \text { q } & \begin{array}{c}\text { Implied } \\ \text { Discount } \\ \text { Rate }\end{array} & \begin{array}{c}\text { After-tax } \\ \text { Rate of Return }\end{array} \\ 1951-55 & .71 & 6.47 \% & .4 .54 \% \\ 1956-60 & .83 & 5.15 & 4.27 \\ 1961-65 & .98 & 5.74 & 5.61 \\ 1966-70 & .98 & 5.80 & 5.68 \\ 1971-75 & .77 & 5.93 & 4.48 \\ 1976-80 & .60 & 7.21 & 4.28 \\ 1981-85 & .64 & 7.42 & 4.80\end{array}$

SOURCES: Board of Governors (1987A), U.S. Department of Commerce, Bureau of Economic Analysis (1986A, Tables 1.16 and $8.8)$ and updates.

NOTES: Tobin's $q$ is the market value of nonfinancial corporations divided by the replacement value of their assets. Market value is the sum of credit market debt and the market value of equities. Replacement value of assets equals total assets minus profit taxes payable, trade debt, and foreign direct investment in the U.S. After-tax rate of return equals after-tax net operating surplus divided by replacement value of assets. Implied discount rate equals after-tax rate of return divided by q. See notes to Figure 2 for net operating suplus. 
Table 9. Trends in Gross Profit Rates, Eleven Countries, Manufacturing and Total Business Sector, 1960-82.

Country

U.S.

Germany

France

$\mathrm{U} \cdot \mathrm{K}$.

Canada

Belgium

Finland

Sweden

Addendum :

Gross Operating

Surplus Share

Japan

Italy

Norway
Growth Rates

Per Cent Per Annum

Manufacturing Total Business Sector

$-2 \cdot 7$

$-3.0$

$-2.7$

$-5.3$

$-2.0$

$-4.7$

$-2.8^{* k}$

$-5.2$

$-2.1$

$-2.0$

$-1.9$

$-1.9$

$-0.8$

$-1.4$

$-4.3$

$-2.8$

SOURCE: Chan-Lee and Sutch (1985A, Tables 3 and 4).

NOTES: Trend rates estimated from in $r=a+b t$. Asterisk (*) indicates not significant at the 5 per cent level. 
Table 10. Alternative Measures of Nonfinancial Corporate Capital Formation and Profitability, U.S., Selected Years.

Years

$1981-85$

$1951-55 \quad 1956-60 \quad 1961-65 \quad 1966-70 \quad 1971-75 \quad 1976-80$

Gross Investment

as a percentage

of NFC GDP

$12.7-13.1$

12.4

13.7

$13 \cdot 4$

14.7

14.6

Net Investment

as a percentage

of NFC NDP

$\begin{array}{lll}5.0 & 4.5 & 4.4\end{array}$

5.9

$4 \cdot 5$

4.8

3.6

Net investment

$(\$ 82)$ as a

percentage of

net $f$ ixed

capital (\$82)

$4.2 \quad 3.5 \quad 3.8$

5.1

3.6

$3 \cdot 6$

2.7

Growth rate of

ratio of net fixed

capital (\$82) to

hours

0.50

2.28

2.50

0.05

1.09

Ratio of net

fixed capital

to NFC NDP

$1.69 \quad 1.76 \quad 1.58$

1.56

1.74

1.86

1.87

After-tax net operating surplus

as a percentage

of NFC NDP

$9.8 \quad 10.0$

$12 \cdot 2$

11.8

10.2

10.4

$11 \cdot 7$

After-tax net

rate of profit

(per cent)

\subsection{7}

5.68

7.70

7.59

5.91

5.57

6.31

SOURCES: U.S. Department of Commerce, Bureau of Economic Analysis (1986A, Tables 1.16 and 8.8) and updates, Board of Governors (1987B), CITIBASE, Musgrave (1986, Tables 6 and 8 ) and updates, U.S. President (1987, Table B-3).

NOTES: Nonfinancial corporate (NFC) gross domestic product (GDP) is the sum of capital consumption allowances with CCAdj, indirect business taxes, compensation of employees, corporate profits with IVA and CCAdj, and net monetary interest. Net domestic product (NDP) is GDP minus capital consumption allowances with CCAdj. Gross investment is Flow of Funds category "fixed investment." Net investment is fixed investment less depreciation charges, NIPA, deflated by implicit price deflator for nonresidential fixed investment to give net investment in 1982 constant dollars. For net operating surplus and net rate of profit, see notes to Figure 2 . 
Table 11. Capital Productivity in the Manufacturing Sector, Eleven Countries, 1960-82.

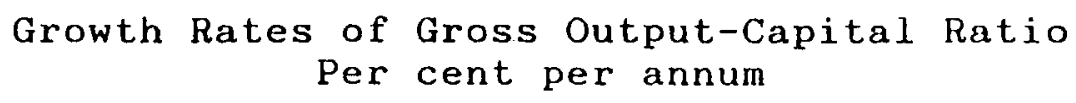

\begin{tabular}{crr}
$\begin{array}{c}\text { Implied } \\
\text { Full Period } \\
\text { Trend }\end{array}$ & $1960-72$ & $1972-82$ \\
(Nominal Ratio) & \multicolumn{2}{c}{ (Real Ratio) } \\
& & -2.2 \\
-1.9 & 2.4 & 0.4 \\
-3.0 & 0.5 & -0.7 \\
-1.3 & -1.2 & -2.3 \\
-1.1 & 2.6 & -2.6 \\
-2.5 & 4.8 & 0.7 \\
1.1 & -2.4 & -3.8 \\
-1.4 & 1.6 & 1.1 \\
0.8 & 4.8 & 0.4 \\
-2.2 & 5.0 & -4.0 \\
1.0 & 0.2 & -3.2 \\
-2.8 & 0.1 &
\end{tabular}

SOURCE: Chan-Lee and Sutch (1985A, Tables 3,4 , and 23 ).

NOTES: Growth rates in column one have not been estimated directly. They are the difference between trend growth rates in the gross profit rate and the gross profit share found by regressing logs on time. Column one refers to nominal output-capital ratios; columns two and three refer to real output-capital ratios. The earliest endpoints in column two frequently are later than 1960 owing to data availability. Consult notes to Chan Lee and Sutch (Table 23). 
Figure 1. Before-tax Profit Rate, U.S. Nonfinancial Corporate Sector, 1948-85.

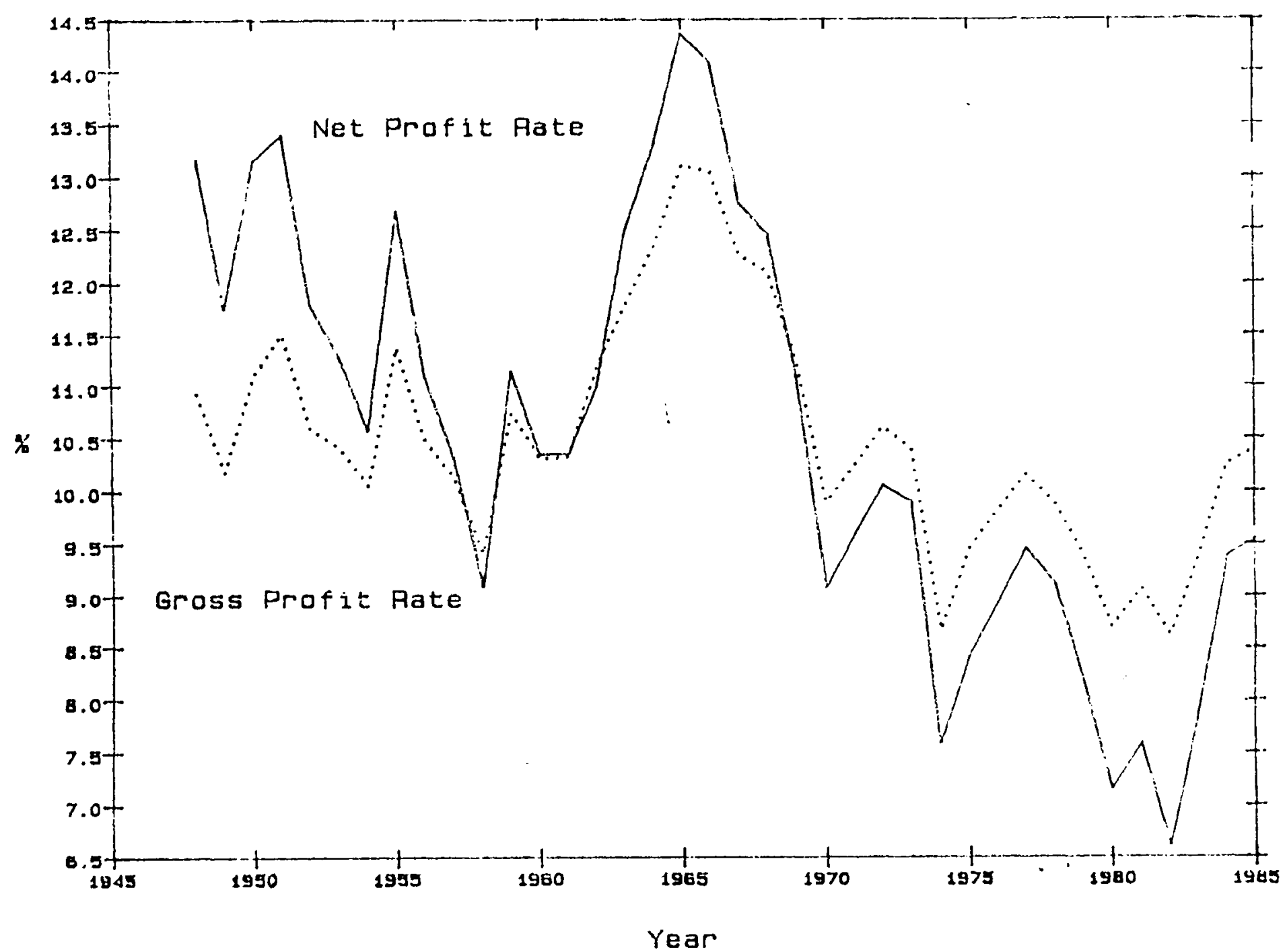

SOURCES: U.S. Department of Commerce, Bureau of Economic Analysis (1986A, Tables 1.16 and 8,8) and updates; Musgrave (1986, Tables 5 and 6) and updates; Board of Governors (1987A),

NOTES: Gross (net) before-tax rate of profit is gross (net) before-tax operating surplus divided by the sum of gross (net) fixed nonresidential capital stock, end-of-year inventories, and end-ofyear demand deposits and currency. Gross operating surplus is profits before tax with IVA and CCAdj plus capital consumption allowances with CCAdj plus net monetary interest paid, Net operating surplus is profits before tax with IVA and CCAdj plus net monetary interest paid. 
Figure 2. After-tax Profit Rate, U.S. Nonfinancial Corporate Sector, 1948-85.

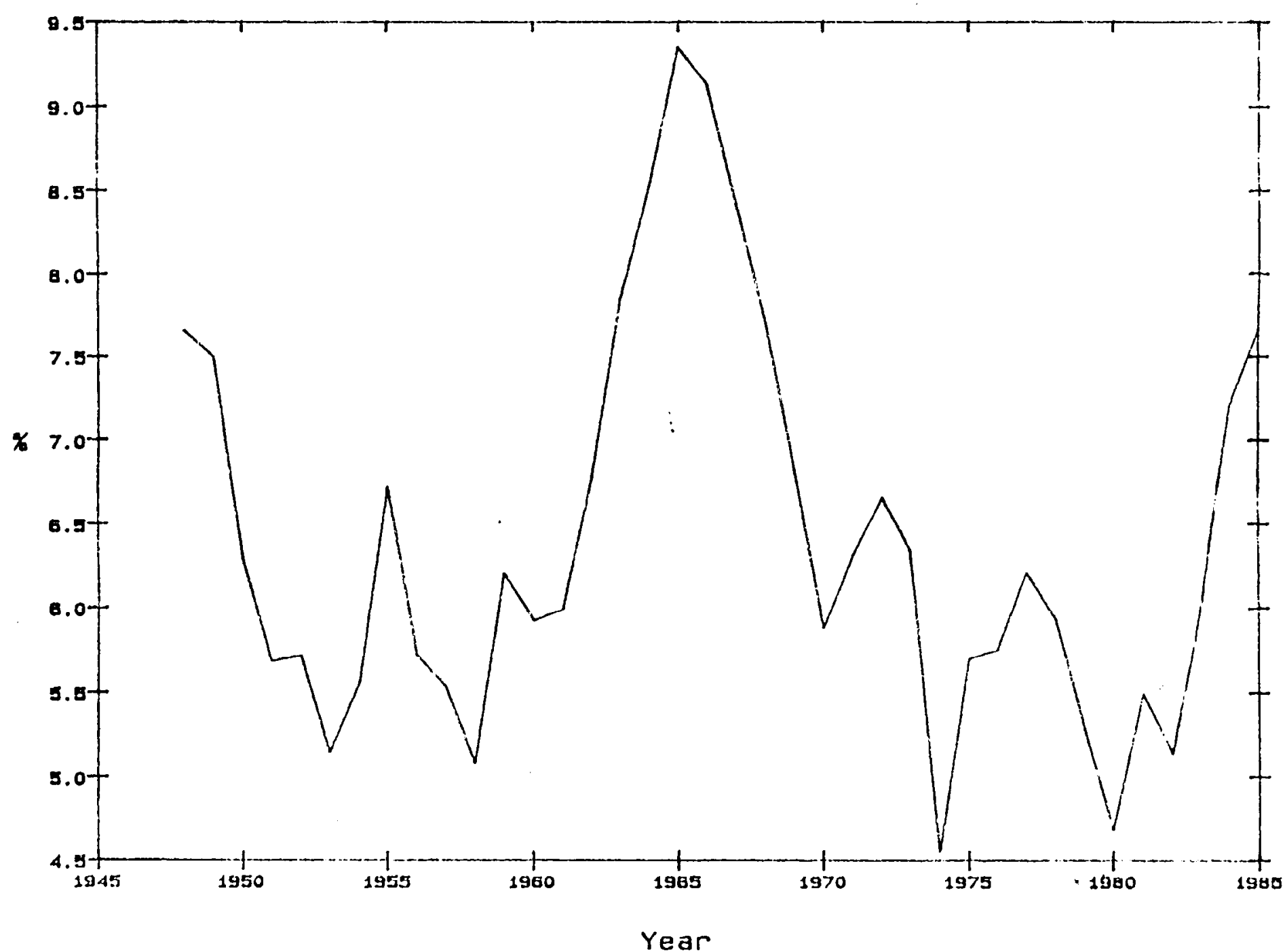

SOURCES: See notes to Figure 1.

NOTES: Net after-tax rate of profit is the after-tax net operating surplus divided by the sum of net fixed nonresidential capital stock, end-of-year inventories, and end-of-year demand deposits and currency. Net operating surplus is profits after tax plus IVA and CCAdj plus net monetary interest paid. 
Figure 3. Net Capital-output Ratios, U.S. Nonfinancial Corporate Sector, 1948-85

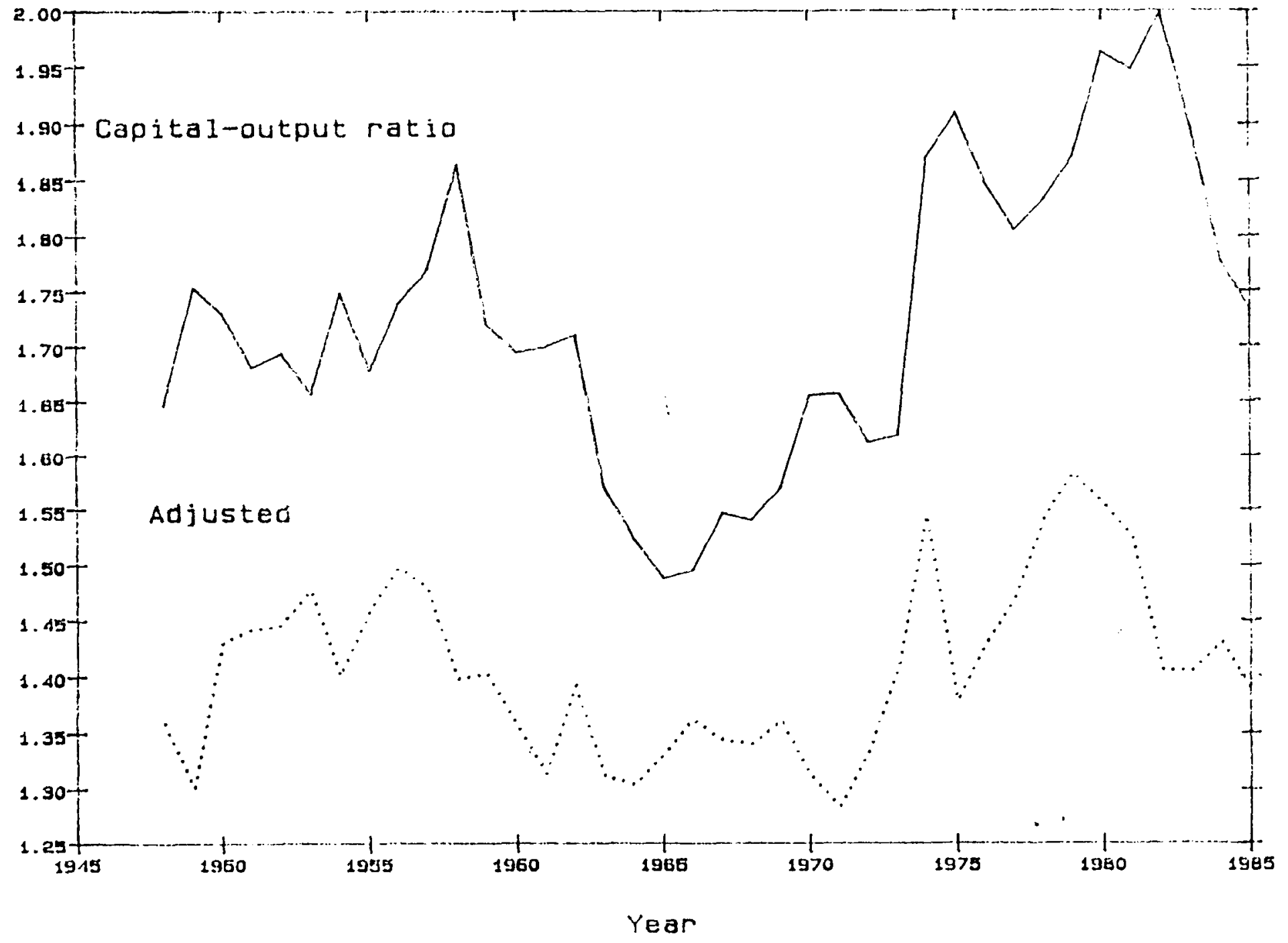

SOURCES: U.S. Department of Commerce, Bureau of Economic Analysis (1986A, Tables 1.16 and 8.8) and updates; Nusgrave (1986, Table 6) and updates; CITIBASE.

NOTES: Capital-output ratio is net fixed nonresidential capital stock in current dollars divided by net domestic product of the nonfinancial corporate sector. See notes to lable 10 for net domestic product. Adjusted capita1-output ratio is multiplied by the Federal Reserve Board's capacity utilization index for manufacturing. 
Figure 4. Net Operating Surplus and Net Investment in Constant Dollars, U.S. Nonfinancial Corporate Sector, 1948-85.

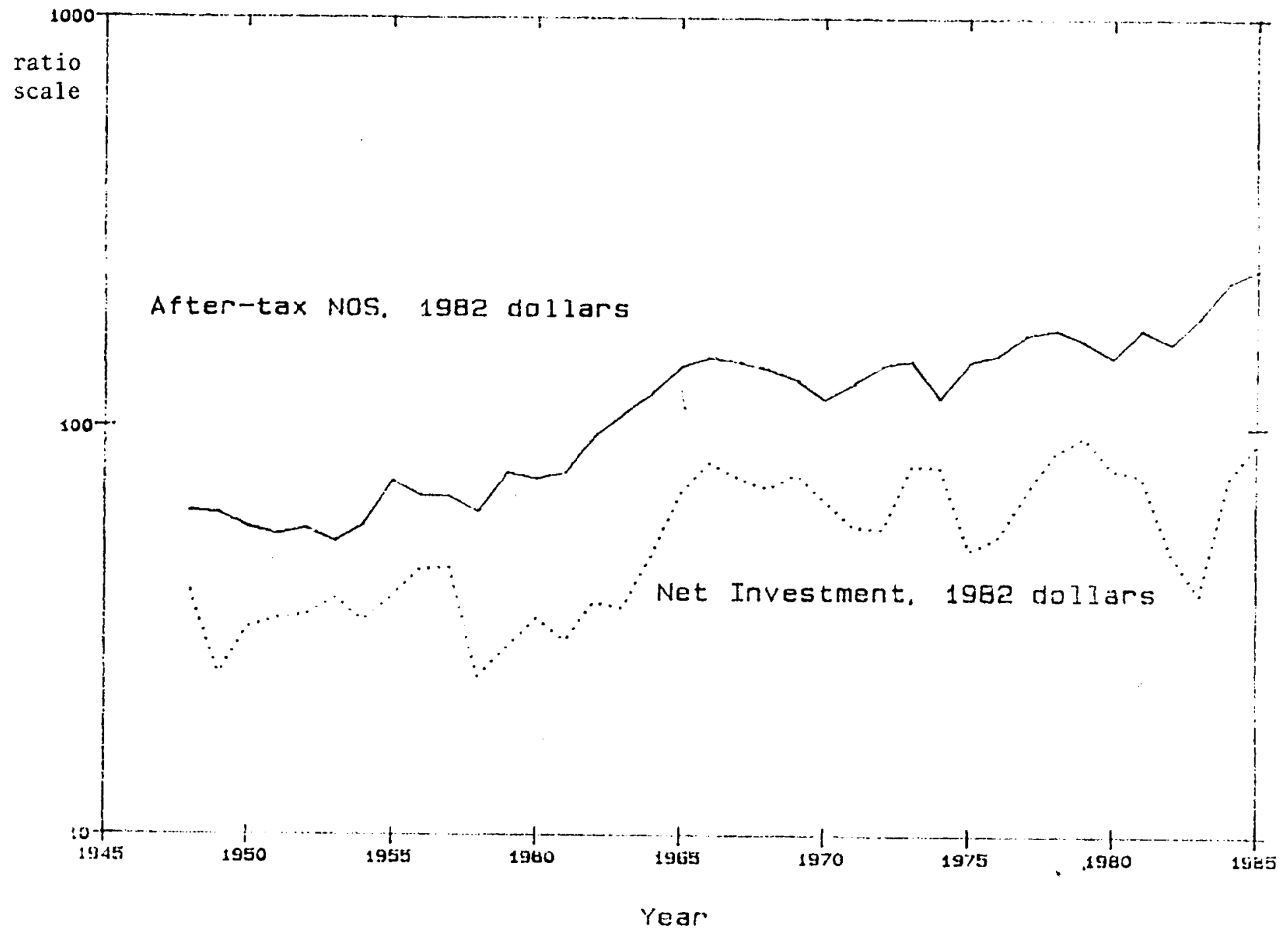

SOURCES: See notes to Table 10 .

NOTES: After-tax net operating surplus is deflated by the implicit price deflator for nonfinancial corporate net domestic product. For net operating surplus and deflated net investment, see notes to Table 10 . 
Figure 5. Effective Tax Rates on Capital Income, Various Definitions, U.S. Nonfinancial Corporate Sector, 1948-85,

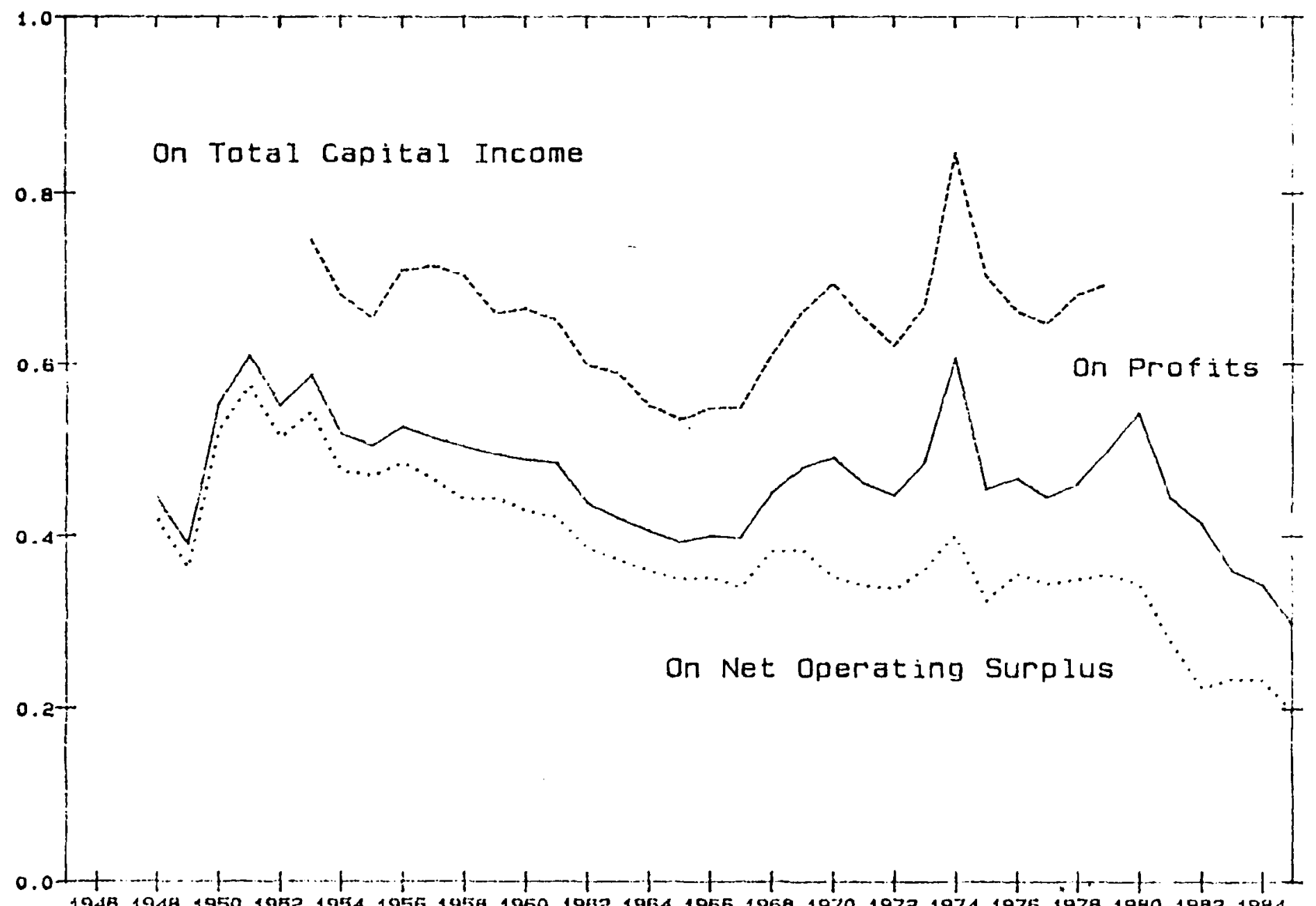

\section{Year}

SOURCES: U.S. Department of Commerce, Bureau of Economic Analysis (1986A, Tables 1.16 and 8.8) and updates; Feldstein, et. al. (1983, Table 4).

NOTES: Effective tax rate on profits is profits tax liability divided by profits before tax with IVA and CCAdj. Effective tax rate on net operating surplus is profits tax liability divided by before-tax net operating surplus. See notes to Figure 1 for net operating surplus. For effective tax rate on total capital income, consult Feldstein, et a1. (1983) or text. 


\section{BIBL IOGRAPHY}

Abel, A. B. and Blanchard, O. J. (1986). "The present value of profits and cyclical movements in investments,"

Econometrica, 54, pp. 249-73.

Allman, D. N. (1983). "The decline in business profitability: a disaggregated analysis," Economic Review, Federal Reserve Bank of Kansas City, (January), pp. 19-26.

Aquino, A. (1978). "Intra-industry trade and inter-industry specialization as concurrent sources of international trade in manufactures," Weltwirtschaftliches Archiv, 114 , pp. $172-95$.

Asimakopolous, A. (1983). "Kalecki and Keynes on finance, investment, and saving," Cambridge Journal of Economics, 7 , (September/December), pp. 221-33.

. (1971). "The determination of investment in Keynes's model," Canadian Journal of Economics, 4, (August), pp. $382-88$.

Asimakopolous, A., and Burbidge, J. B. (1974). "The short-period incidence of taxation," Economic Journal, 84, (June), pp. $267-88$.

Atkinson, A. B., and Stiglitz, J. E. (1980). Lectures on public economics. New York: McGraw Hill Book Company.

Bayer, K. (1984). "Profitability in Austrian industrial corporations," in D. M. Holland, ed., Measuring profitability and capital costs: an international study. Lexington : Lexington Books.

Board of Governors of the Federal Reserve System. (1987A). Balance sheets of the U.S. economy, 1947-86. (May).

- (1987B). "Sector statements of saving and investment," Flow of Funds Accounts, printout (January).

Boddy, R. and Crotty, J. (1975). "Class conflict and macropolicy: the political business cycle," Review of Radical Political Economics, 7, (Spring), pp. 1-19.

Bosworth, B. P. (1985). "Taxes and the investment recovery," Brookings Papers on Economic Activity, 1, pp. 1-38.

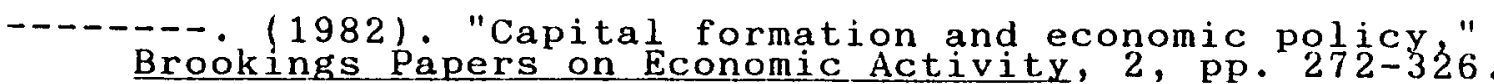


Bowles, S. (1985). "The production process in a competitive economy: Walrasian, neo-Hobbesian, and Marxian models," American Economic Review, 75, (March), pp. 16-36.

Bowles, S., Gordon, D. M. and Weisskopf, T. E. (1986). "Power and profits: the social structure of accumulation and the profitability of the postwar U.S. economy, "Review of Radical Political Economy, 18 , (Spring \& Summer), pp. 13267 .

Brainard, W. C., Shoven, J. B., and Weiss, L. (1980). "The financial valuation of the return to capital," Brookings Papers on Economic Activity, 2, pp. 453-502.

Bruno, M. and Sachs, J. D. (1985). Economics of worldwide stagflation. Cambridge: Harvard University Press.

Bulow, J., and Shoven, J. B. (1982). "Inflation, corporate profits, and the rate of return to capital," in Robert Hall, ed. Inflation: causes and effects. Chicago: University of Chicago Press.

Chan-Lee, J. H . (1986). "Pure profit rates and Tobin's q in nine OECD countries," OECD Economic Studies, 7, (Autumn), pp. 205-32.

Chan-Lee, J. H., and Sutch, H. (1985A). "Profits and rates of return in OECD countries," OECD Department of Economics and Statistics Working Paper No. 20, (May), Paris: OECD.

OECD Economic Studies, 5, (Autumn), pp. 127-67.

Clark, P. K. (1984). "Productivity and profits in the 1980s: are they really improving?" Brookings Papers on Economic Activity, 1 , pp. 133-63.

and prediction," Brookings Papers on Economic Activity, 1 , pp. 73-113.

Coutts, K., Godley, W., and Nordhaus, W. (1978). Industrial pricing in the U.K. Cambridge: Cambridge University Press.

Corcoran, P. J. (1977). "Inflation, taxes, and corporate investment incentives," Federal Reserve Bank of New York Quarterly Review, (Autumn) pp. 1-10.

Duesenberry, J. S. (1958). Business cycles and economic growth. New York: McGraw-Hill Book Company. 
Dutt, A. K. (1984). "Stagnation, income distribution, and monopoly power," Cambridge Journal of Economics, 8, (March), pp. $25-40$.

Eisncr, R. (1980). "Capital gains and income: real changes in value of capital in the United States, 1946-77," in Dan Usher, ed. The measurement of capital. Chicago: University of Chicago Press.

Eisner, R., and Strotz, R. H. (1963). "Determinants of business investment," in Commission on Money and Credit, Impacts of monetary policy. Englewood Cliffs: Prentice-Hall, Inc.

Fay, J. A., and Medoff, J. L. (1985). "Labor and output over the business cycle: some direct evidence," American Economic Review, 75, (September), pp. 638-55.

Fazzari, S. M., and Mott, T. L. (1986/87). "The investment theories of Kalecki and Keynes: an empirical study of firm data, 1970-1982," Journal of Post Keynesian Economics, 9, (winter), pp. 171-87.

Financial Accounting Standards Board. (1984). Accounting standards: orignal pronouncements. New York: McGraw-Hill Book Company.

Feldstein, M., Dicks-Mireaux, L., and Poterba, J. (1983). "The effective tax rate and the pretax rate of return," Journal of Public Economics, 21, (July), pp. 129-58.

Feldstein, M., and Summers, L. (1977). "Is the rate of profit falling?" Brookings Papers on Economic Activity, 1, pp. 211 77 .

Fisher, F. M., and McGowen, J. J. (1983). "On the misuse of accounting rates of return to infer monopoly profits," American Economic Review, 73, (March), pp. 82-97.

Foley, D. K. (1987). "Liquidity-profit rate cycles in a capitalist economy," Journal of Economic Behavior and Organization, 8, (Forthcoming).

- (1986A). Money, accumulation, and crisis. New York: Harwood Academic Publishers.

- (1986B). Understanding capital: Marx's economic theory. Cambridge: Harvard University Press.

Funke, M. (1986). "Influences on the profitability of the manufacturing sector in the U.K.--an empirical study," Oxford Bulletin of Economics and Statistics, 48, (May), pp. $165-87$. 
Glyn, A., and Sutcliffe, B. (1972). Capitalism in crisis. New York: Pantheon Books.

Goodwin, R. M. (1967). "A growth cycle," in C. H. Feinstein, ed. Capitalisme socialism, and economic growth: essays presented to Maurice Dobb. Cambridge: The University Press.

Gordon, D. M., Edwards, R. C., and Reich, M. (1982). Segmented work, divided workers: the historical transformation of work in the U. S.. Cambridge: Cambridge University Press.

Gordon, R. J. (1967). "The incidence of the corporation income tax in U.S. manufacturing, 1925-62," American Economic Review, 57 , (September), pp. 731-58.

Gordon, R. J., and Veitch, J. M. (1984). "Fixed investment in the American business cycle, 1919-83," NBER Working Paper \#1426, (August), Cambridge: National Bureau of Economic Research.

Gorman, J. A., et. al. (1985). "Fixed private capital in the United States," Survey of Current Business, 65, (July), pp. $36-59$.

Grimm, B. T. (1982) . "Domestic nonfinancial corporate profits," Survey of Current Business, 62, (January), pp. 30-42.

Hall, R. E. (1986). "Market structures and macroeconomic fluctuations," Brookings Papers on Economic Activity, 2, pp. $285-338$.

Hahnel, R., and Sherman, H. (1982). "The rate of profit over the business cycle," Cambridge Journal of Economics, 6, (June), pp. 185-94 .

Harberger, A. C. (1983). "The state of the corporate income tax: who pays it? should it be repealed?" in C. E. Walker and $M$. A. Bloomfield, eds. New directions in federal tax policy for the 1980s. Cambridge: Ballinger.

- (1962). "The incidence of the corporation income tax," Journal of Political Economy, 70, (June), pp. 215-48.

Harcourt, G. C. (1972). Some Cambridge controversies in the theory of capital. Cambridge: Cambridge University Press.

- (1965). "The accountant in a golden age," Oxford Economic Papers, 17, (March), pp. 66-80.

Harris, D. J. (1978). Capital accumulation and income distribution. Stanford: Stanford University Press. 
Hill, T. P. (1979). Profits and rates of return. Paris: OECD.

Hinderliter, R. H. (1984). "Sources of change in rates of return on capital: 1952-82," Economic Review of the Federal Reserve Bank of Cleveland, (Fall), pp. 17-37.

Holland, D. M., ed. (1984). Measuring profitability and capital costs: an international study. Lexington: Lexington Books.

Holland, D. M., and Meyers, S. C. (1984). "Trends in corporate profitability and capital costs in the United States," in D. M. Holland, ed. Measuring profitability and capital costs: an international study. Lexington: Lexington Books.

\section{(1979). "Trends in corporate} profitability and capital costs," in R. Linsay, ed., The nation's capital needs: three studies. New York: Committee for Economic Development.

Jorgenson, D. W. (1971). "Econometric studies of investment behavior: a survey," Journal of Economic Literature, 9, (December), pp. 1111-1147.

Kaldor, N. (1956). "Alternative theories of distribution," Review of Economic Studies, 23, pp. 83-100.

Kalecki, M. (1971). Selected essays on the dynamics of the capitalist economy: 1933-1970. Cambridge: Cambridge University Press.

Keynes, J. M. (1930). A treatise on money. New York: Harcourt, Brace, and Company.

King, M. A., and Fullerton, D., eds. (1983). The taxation of income from capital: a comparative study of the United States, the United Kingdom, Sweden, and West Germany. Chicago: University of Chicago Press.

Knight, F. H. (1984). "Profit," Encyclopedia of the Social Sciences, 12, New York: Macmillan.

Kopke, R. W. (1985) . "The determinants of investment spending," New England Economic Review, (July/August), pp. 19-35.

- (1982). "The continuing decline in corporate profitability and stock prices," New England Economic Review, (July/August), pp. 5-17.

- (1978). "The decline in corporate profitability," New England Economic Review, (May/June), pp. 36-60. 
Krzyzaniak, M., and Musgrave, R. A. (1964). The shifting of the corporation income tax. Baltimore: Johns Hopkins Press.

Leontief, W. (1985). "The choice of technology," Scientific American, 252, (June), pp. 37-45.

Liebling, H. I. (1980). U.S. corporate profitability and capital formation. New York: Pergamon Press.

Lovell, M. C. (1978). "The profit picture: trends and cycles," Brookings Papers on Economic Activity, 3, pp. 769-88.

Malinvaud, E. (1984). Mass unemployment. New York: Basil Blackwell.

- 92, (March), pp. 1-12.

- (1980). Profitability and unemployment. Cambridge:

Cambridge University Press.

- (1977). The theory of unemployment reconsidered.

Oxford: Blackwell.

Marglin, S. A. (1984A). Growth, distribution, and prices.

Cambridge: Harvard University Press.

- (1984B). "Growth, distribution, and inflation: a centennial synthesis," Cambridge Journal of Economics, 8, (June), pp. 115-44.

Marrelli, M., and Salvadori, N. (1983). "Tax incidence and growth models," Public Finance, 38, (December), pp. 409-18.

Meyer, J., and Kuh, E. (1957). The investment decision. Cambridge: Harvard University Press.

Minsky, H. (1986). Stabilizing an unstable economy. New Haven: Yale University Press.

Modigliani, F., and Cohn, R. A. (1979). "Inflation, rational valuation, and the market," Financial Analysts Journal, 35, (March/April), pp. 24-44.

Moseley, F. (1985). "The rate of surplus value in the postwar U. S. economy: a critique of Weisskopf's estimates," Cambridge Journal of Economics, 9, (March), pp. 57-79.

Munley, R. (1981). "Wages, salaries, and the profit share: a reassessment of the evidence," Cambridge Journal of Economics, 5, (June), pp. 159-73. 
Musgrave, J. C. (1986). "Fixed reproducible tangible wealth in the United States, revised estimates," Survey of Current Business, 66, (January), pp. 51-75.

Nell, E. (1985). "Jean Baptiste Marglin: a comment on 'Growth, distribution and inflation', "Cambridge Journal of Economics, 9, (June), pp. 173-78.

Nordhaus, W. D. (1974). "The falling share of profits," Brookings Papers on Economic Activity, 1, pp. 169-208.

Nordhaus, W. D., and Godley, W. A. H. (1972). "Pricing in the trade cycle," Economic Journal, 82, (June), pp. 853-83.

Okishio, N. (1961). "Technical changes and the rate of profit," Kobe University Economic Review, 7 , pp. 85-99.

Okun, A. M., and Perry, G. L. (1970). "Notes and numbers on the profit squeeze," Brookings Papers on Economic Activity, 3 , pp. $417-72$.

Okun, A. M. (1981). Prices and quantities: a macroeconomic analysis. Washington D.C.: The Brookings Institute.

Pasinetti, L. L. (1974). Growth and income distribution: essays in economic theory. Cambridge: Cambridge University Press.

Parker, R. P., and Fox, D. R. (1985). "Revised estimates of the NIPAs of the United States, 1929-85: an introduction," Survey of Current Business, 65, (December), pp. 1-19.

Pigou, A. C. (1941). "Maintaining capital intact," Economica, new series, 8, (August), pp. 271-75.

Pollin, R. (1986). "Alternative perspectives on the rise of corporate debt dependency: the U.S. postwar experience," Review of Radical Political Economics, 18, (Spring/Summer), pp. 205-35.

Robinson, J. (1964). Essays in the theory of economic growth. New York: St. Martin's Press.

Ruggles, R., and Ruggles, N. D. (1982). "Integrated economic accounts for the United States, 1947-80," Survey of Current Business, 63, (May), pp. 1-65.

York: Columbia University Press.

economic analysis. New York: McGraw-Hill Book Company. 
Runyon, H. (1979). "Profits: a declining share to capital?" Business Economics, 14, (September), pp. 85-94.

Sachs, J. D. (1979). "Wages, profits, and macroeconomic adjustment: a comparative study," Brookings Papers on Economic Activity, 2, pp. 209-319.

Salvadori, N. (1981). "Falling rate of profit with a constant real wage: an example," Cambridge Journal of Economics, 5, $($ March), pp. 59-66.

Scanlon, M. S. (1981). "Postwar trends in corporate rates" of return," in Board of Governors of the Federal Reserve System, Public policy and capital formation. Washington: Federal Reserve System.

Schultze, C. L. (1975). "Falling profits, rising profit margins, and the full employment profit rate," Brookings Papers on Economic Activity, 2, pp. 449-71.

Shaikh, A. (1978). "Political economy and capitalism: notes on Dobb's theory of crisis," Cambridge Journal of Economics, 2, (June), pp. 233-51.

Shepherd, W. G. (1982). "Causes of increased competition in the U. S. economy, 1939-1980," The Review of Economics and Statistics, 64, (November), pp. 613-26.

Shiller, R. J. (1981). "Do stock prices move too much to be justified by subsequent changes in dividends?" American Economic Review, 71, (June), pp. 421-36.

Shoven, J. B., and Bulow, J. I. (1976). "Inflation accounting and nonfinancial corporate profits: financial assets and liabilities," Brookings Papers on Economic Activity, 1, pp. $15-66$.

nonfinancial corporate profits: physical assets," Brookings Papers on Economic Activity, 3, pp. 557-661.

Simons, H. C. (1938). Personal income taxation. Chicago: University of Chicago Press.

Steindl, J. (1979). "Stagnation theory and stagnation policy," Cambridge Journal of Economics, 3, (March), pp. 1-14.

Summers, L. (1981). "Taxation and corporate investment: a qtheoretic approach," Brookings Papers on Economic Activity, 1, pp. 67-127. 
Sylos-Labini, P. (1979A). "Industrial pricing in the U.K.," Cambridge Journal of Economics, 3, (March), pp. 153-63.

- (1979B). "Prices and income distribution in manufacturing industries," Journal of Post Keynesian Economics, 2, (Fall), pp. 3-25.

Taylor, L. (1985). "A stagnationist model of economic growth," Cambridge Journal of Economics, 9, (December), pp. 383-404.

Tinbergen, J. (1938). "Statistical evidence on the acceleration principle," Economica, 5, (May), pp. 164-78.

Tobin, J., and Brainard, W. C. (1977). "Asset markets and the cost of capital," in B. Belassa and R. Nelson, eds., Economic progress, private values and public policy: essays in honor of William Fellner. Amsterdam: North-Holland.

Ueda, K., and Yoshikawa, H. (1986). "Financial volatility and the q-theory of investment," Economica, 53, (February), pp. 1127 .

U. S. Department of Commerce, Bureau of Economic Analysis. $(1986 \mathrm{~A})$. The national income and product accounts, 1929-82. Washington D. C.: GPO.

- (1986B). "The U. S. NIPAs: revised estimates," Survey of Current Business, $66,(J u l y)$, pp. 7-23.

---- (1985A). Corporate profits: profits before tax, profits tax liability, and dividends. Methodology Paper Series MP-2, Washington D. C.: GPO.

- (1985B). Business Statistics 1984, 24th edition. A supplement to the Survey of Current Business. Washington: GPO.

-.--- (1976). Readings in concepts and methods of national income statistics. Springfield VA: National Technical Information Service.

U. S. Department of Commerce, Bureau of the Census. (1986). General Summary, 1982 , Census of Manufactures Part 1. Washington D. C.: GrO.

U. S. Department of Labor, Bureau of Labor Statistics. (1983). Trends in multifactor productivity, 1948-81. Bulletin 2178, Washington D. C.: GPO.

U. S. President. (1987). The economic report of the president 1987. Washington: GPO. 
Van Parijs, P. (1980). "The falling rate-of-profit theory of crisis: a rational reconstruction by way of obituary," Review of Radical Political Economics, 12, (Spring), pp, 117 .

Von Furstenberg, G. M. (1977). "Corporate investment: does market valuation matter in the aggregate?" Brookings Papers on Economic Activity, 2, pp. 347-97.

Weisskopf, T. E. (1981). "Wages, salaries, and the profit share: a rejoinder," Cambridge Journal of Economics, 5, (June), pp. $175-82$.

- (1979). "Marxian crisis theory and the rate of profit in the postwar U. S. economy," Cambridge Journal of Economics, 3, (December), pp. 341-78.

Weisskopf, T. E., Bowles, S., and Gordon, D. M. (1983). "Hearts and minds: a social model of U. S . productivity growth," Brookings Papers on Economic Activity, 2, pp. 381-450.

Wolff, E. N. (1986). "The productivity slowdown and the fall in the U.S. rate of profit, 1947-1976," Review of Radical Political Economics, 18, (Spring/Summer), pp. 87-109.

Wood, A. (1975). A theory of profits. Cambridge: Cambridge University Press.

Young, A. H. (1975). "New estimates of capital consumption allowances revision of GNP in the benchmark," Survey of Current Business, 56, (October), pp. 14-35.

Young, A. H., and Musgrave, J. C. (1980). "Estimation of capital stock in the United States," in D. Usher, ed. The measurement of capital. Chicago: University of Chicago Press. 